\title{
PROCESSAMENTO MÍNIMO DE MELÃO RENDILHADO: TIPO DE CORTE, TEMPERATURA DE ARMAZENAMENTO E ATMOSFERA MODIFICADA
}

\author{
MARIA CECÍLIA DE ARRUDA
}

Dissertação apresentada à Escola Superior de Agricultura "Luiz de Queiroz", Universidade de São Paulo, para obtenção do título de Mestre em Agronomia, Área de Concentração: Fitotecnia.

PIRACICABA

Estado de São Paulo - Brasil

Maio - 2002 


\section{PROCESSAMENTO MÍNIMO DE MELÃO RENDILHADO: TIPO DE CORTE, TEMPERATURA DE ARMAZENAMENTO E ATMOSFERA MODIFICADA}

\section{MARIA CECÍLIA DE ARRUDA}

Engenheiro Agrônomo

Orientador: Prof. Dr. ANGELO PEDRO JACOMINO

Dissertação apresentada à Escola Superior de Agricultura "Luiz de Queiroz", Universidade de São Paulo, para obtenção do título de Mestre em Agronomia, Área de Concentração: Fitotecnia.

PIRACICABA

Estado de São Paulo - Brasil

Maio - 2002 


\title{
Dados Internacionais de Catalogação na Publicação (CIP) DIVISÃO DE BIBLIOTECA E DOCUMENTAÇÃO - ESALQ/USP
}

\author{
Amuda, Maria Cecília de \\ Processamento mínimo de melão rendilhado: tipo de corte, \\ temperatura de armazenamento e atmosfera modific ada / Maria Cecilia \\ de Amuda. - - Piracic aba, 2002. \\ $71 \mathrm{p}$. \\ Dissertação (mestrado) - - Escola Superior de Agricultura Luiz de \\ Queiroz, 2002. \\ Bibliografia. \\ 1. Amazenamento refrigera do 2. Embalagens de alimentos 3. Melão \\ 4. Processamento de alimentos 5. Qua lidade dos a limentos I. Título
}

CDD 635.61

"Permitida a cópia total ou parcial deste documento, desde que citada a fonte - $O$ autor" 
À minha família, em especial, meus pais:

Osvaldo e Maria Terezinha pelo apoio e carinho. 


\section{AGRADECIMENTOS}

À Deus, por iluminar meu caminho e possibilitar-me realizar este trabalho, de suma importância para meu aperfeiçoamento profissional.

À Comissão do Curso de Pós-Graduação em Fitotecnia pela oportunidade de realização do curso de mestrado.

À Capes pela concessão da bolsa.

À Fundação de Amparo à Pesquisa do Estado de São Paulo pelo apoio financeiro concedido ao projeto.

Ao Prof. Dr. Angelo Pedro Jacomino pela orientação, incentivo e por toda atenção e dedicação demonstrada em cada etapa deste trabalho.

À Prof . Dra. Marta H. F. Spoto pelo apoio nas análises sensoriais.

Ao Prof. Dr. Cláudio Rosa Gallo pelo apoio nas análises microbiológicas.

Ao Prof. Dr. Francisco de Assis Alves Mourão Filho pela liberação do uso da câmara de fluxo laminar para realização das análises microbiológicas.

Ao Prof. Dr. Ricardo Alfredo Kluge pelo auxílio nas análises estatísticas e pelas revisões realizadas.

Ao Prof. Dr. Cyro Paulino da Costa pela correção dos Summaries. 
Ao Prof. Dr. Rogério Lopes Vieites, que despertou-me o interesse pela área de póscolheita de produtos hortícolas.

À Dra. Claire I. G. L. Sarantópoulos pelo apoio nos experimentos referentes à embalagem.

À Miriam Kluge pelas fotos.

Às empresas Cryovac e Dupont pelo fornecimento das embalagens.

Aos funcionários do Depto de Produção Vegetal, em especial, Aparecido, Barbosa, Bete, Célia, Davi, Éder, Helena, Luciane e Odair pelos mais diversos tipos de ajuda.

Aos integrantes do grupo de pós-colheita, em especial, Flávia e Vanessa, pela colaboração nas análises.

Aos amigos Carolina, Cristiaini, Eduardo, Eliane, Gambé, Marisa, Mirian, Ramón, Sally, Silvana Bortoleto, Silvana Bueno e Sílvio pela força e companheirismo.

Aos colegas do curso de Pós-Graduação em Fitotecnia pela agradável convivência. 


\section{SUMÁRIO}

Página

RESUMO.

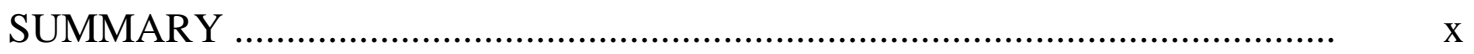

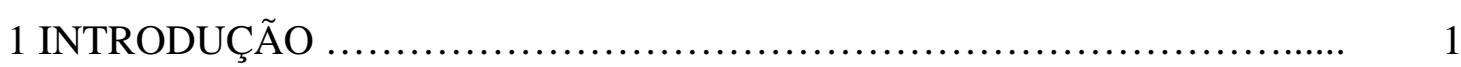

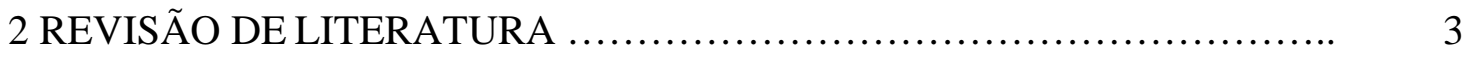

2.1 Aspectos gerais da cultura do melão .............................................................

2.2 Fisiologia pós-colheita do melão .................................................................

2.3 Aspectos gerais sobre o processamento mínimo de frutas e hortaliças ............ 5

2.3.1 Efeito da temperatura ………………………….....................................

2.3.2 Importância da atmosfera modificada …………………………...............

2.3.3 Efeito da umidade relativa ……................................................................

2.3.4 Aspectos fisiológicos e bioquímicos ..........................................................

2.3.5 Microrganismos .................................................................................. 10

2.3.6 Influência do tipo de corte ........................................................................... 11

3 TIPO DE CORTE E TEMPERATURA DE ARMAZENAMENTO PARA MELÃO MINIMAMENTE PROCESSADO 12

Resumo …….................................................................................. 12

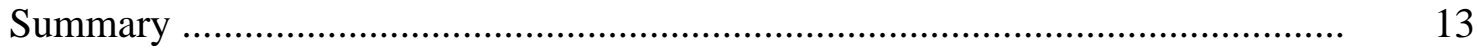

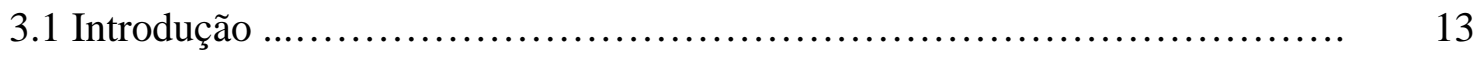

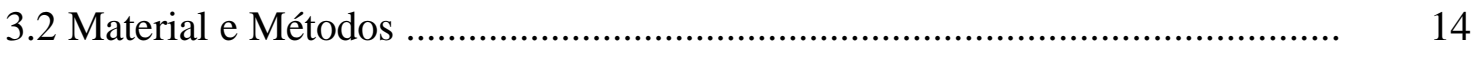

3.3 Resultados e Discussão ......................................................................... 18 
3.4 Conclusões

4 AVALIAÇÃO DE ATMOSFERA MODIFICADA PASSIVA NA QUALIDADE DE MELÃO MINIMAMENTE PROCESSADO

Resumo

Summary 28

4.1 Introdução 29

4.2 Material e Métodos 30

4.3 Resultados e Discussão

4.4 Conclusões

5. AVALIAÇÃO DE ATMOSFERA MODIFICADA ATIVA NA QUALIDADE DE MELÃO MINIMAMENTE PROCESSADO.

Resumo

Summary

5.1 Introdução

5.2 Material e Métodos.

5.3 Resultados e Discussão 50

5.4 Conclusões 60

6. CONCLUSÕES GERAIS 61 ANEXO 62

REFERÊNCIAS BIBLIOGRÁFICAS 65 


\title{
PROCESSAMENTO MÍNIMO DE MELÃO RENDILHADO: TIPO DE CORTE, TEMPERATURA DE ARMAZENAMENTO E ATMOSFERA MODIFICADA
}

\author{
Autora: MARIA CECÍLIA DE ARRUDA \\ Orientador: Prof. Dr. ANGELO PEDRO JACOMINO
}

\section{RESUMO}

Os objetivos deste trabalho foram determinar o tipo de corte, a temperatura de armazenamento e os materiais de embalagem que proporcionam melhor manutenção da qualidade de melão minimamente processado. No primeiro experimento foram testados dois tipos de corte (cubo e fatia) e três temperaturas de armazenamento $\left(3^{\circ}, 6^{\circ}\right.$ e $\left.9^{\circ} \mathrm{C}\right)$. No segundo experimento os melões minimamente processados em cubos foram acondicionados em diversos materiais de embalagem e armazenados à $3^{\circ} \mathrm{C}$. Os materiais de embalagem foram: AFG: filme poliolefínico com antifog da DuPont 15 $\mu \mathrm{m}$; HP: filme

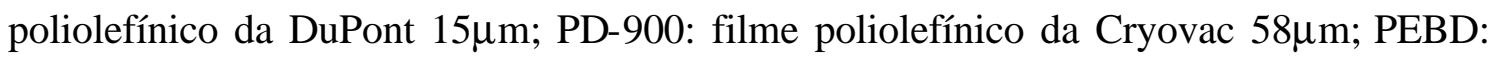
filme de polietileno de baixa densidade $87 \mu \mathrm{m}$; PP: filme de polipropileno $52 \mu \mathrm{m}$; BB200: filme multicamada da Cryovac $65 \mu \mathrm{m}$ e PET: embalagem rígida de polietileno tereftalato. No terceiro experimento foi testado a injeção da mistura gasosa $\left(5 \% \mathrm{O}_{2}+\right.$ $20 \% \mathrm{CO}_{2}+75 \% \mathrm{~N}_{2}$ ) em 3 diferentes materiais de embalagem: BB-200: filme multicamada da Cryovac $65 \mu \mathrm{m}$; PBC: filme poliolefínico Probag Conservax $64 \mu \mathrm{m}$ e PP: filme de polipropileno $52 \mu \mathrm{m}$ e o armazenamento foi realizado à $3^{\circ} \mathrm{C}$. Melões acondicionados em embalagem com perfurações foram utilizados como controle. Todos os materiais de embalagem utilizados neste trabalho tiveram sua taxa de permeabilidade ao $\mathrm{O}_{2}$ e $\mathrm{CO}_{2}$ determinadas. No primeiro experimento foram determinadas as 
características físico-químicas e sensoriais a cada 3 dias por um período de 9 dias. No segundo experimento foi realizado um monitoramento da composição gasosa do espaço livre das embalagens durante 8 dias e no $9^{\circ}$ dia avaliou-se as características físicoquímicas e sensoriais. No terceiro experimento determinou-se as características físicoquímicas, sensoriais, microbiológicas e a composição gasosa do espaço livre das embalagens a cada 3 dias durante 12 dias. Os tipos de corte estudados não influenciaram a qualidade do melão. $\mathrm{O}$ armazenamento à $3^{\circ} \mathrm{C}$ apresentou maior eficiência na manutenção da firmeza e das características sensoriais. Os filmes AFG e HP apresentaram alta taxa de permeabilidade ao $\mathrm{O}_{2}$ e $\mathrm{CO}_{2}$ e praticamente não possibilitaram a modificação da atmosfera. Os filmes PD-900, PEBD, PP e BB-200 apresentaram as menores taxas de permeabilidade aos gases, porém a modificação da atmosfera do interior destes filmes foi pequena. A embalagem rígida, apesar de alta taxa de permeabilidade aos gases, promoveu maior modificação da atmosfera, provavelmente devido à menor relação área de permeação da embalagem/massa de melão, porém o equilíbrio dos gases nesta embalagem só ocorreu após o $6^{\circ}$ dia. Em todos os filmes as características físico-químicas foram mantidas, enquanto as características sensoriais foram mantidas apenas nos melões em embalagem de PET. A injeção de $5 \%$ de $\mathrm{O}_{2}+$ $20 \% \mathrm{CO}_{2}+75 \% \mathrm{~N}_{2}$ nos filmes BB-200, PP e PBC teve pouca influência nas características sensoriais e físico-química dos melões. Verificou-se que a injeção da mistura gasosa (independente da embalagem) controlou o crescimento de microorganismos e que os melões do controle apresentaram alta contagem de bactérias mesófilas a partir do $9^{\circ}$ dia. 


\section{FRESH CUT NET MELON: CUT TYPE, STORAGE TEMPERATURE AND MODIFIED ATMOSPHERE}

Author: MARIA CECÍLIA DE ARRUDA

Adviser: Prof. Dr. ANGELO PEDRO JACOMINO

\section{SUMMARY}

The objective of this work was to determine the cut type, storage temperature and packaging materials for better quality maintenance in minimally processed melons. In the first experiment two cut types (cube and slice) and three storage temperatures (3, 6 and $9^{\circ} \mathrm{C}$ ) were evaluated. In the second experiment minimally processed melon in cubes were wrapped in several packaging materials with passive modified atmosphere and stored at $3^{\circ} \mathrm{C}$. The packaging materials were: AFG: DuPont polyolephinic antifog film 15 $\mu$ m; HP: DuPont polyolephinic film $15 \mu \mathrm{m}$, PD-900: Cryovac polyolephinic film 58 $\mu \mathrm{m}$, PEBD: low density polyethylene film $87 \mu \mathrm{m}$, PP: polypropylene film $52 \mu \mathrm{m}$; BB200: Cryovac multlayer film $65 \mu \mathrm{m}$ and PET: rigid polyethylene terephthalate tray. In the third experiment the melons were wrapped in several packaging materials with active modified atmosphere $\left(5 \% \mathrm{O}_{2}+20 \% \mathrm{CO}_{2}+75 \% \mathrm{~N}_{2}\right)$ and stored at $3^{\circ} \mathrm{C}$. The packaging

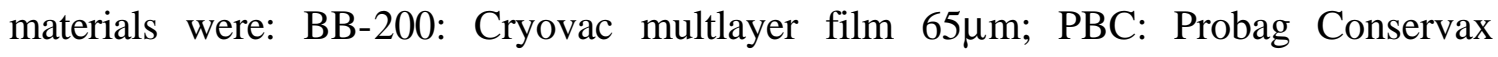
polyolephinic film $64 \mu \mathrm{m}$ and PP: polypropylene film $52 \mu \mathrm{m}$. Melons wrapped in packaging with perforations were used as control. The gas permeability of each film was determined. In the first experiment physicalchemical and sensorial characteristics were determined each 3 days during 9 days. In the second experiment gases composition analyses were monitoring during 8 days and in the $9^{\text {th }}$ day physical-chemical and sensorial characteristics were determined. In the third experiment 
physicalchemical, sensorial and microbiological characteristics and the gas composition were evaluated each 3 days during 12 days. Cut types did not influence the melon quality. The storage at $3^{\circ} \mathrm{C}$ had higher efficiency maintaining firmness and sensorial characteristics. Films AFG and $\mathrm{HP}$ had high rate permeability to $\mathrm{O}_{2}$ and $\mathrm{CO}_{2}$ and practically did not allow atmosphere modification. Films PD-900, PEBD, PP and BB200 had the smallest rate permeability to gases, even when the modification of the interior atmosphere of these films was small. The rigid packaging despite high permeability rate to the gases, promoted large atmosphere modification, probably due to the smallest relationship permeation area of the packaging: melon mass, but gases balance happened only after the $6^{\text {th }}$ day. The physicalchemical characteristics were maintained in all films, while the sensorial characteristics were maintained only the PET packing. Modified atmosphere by injection of $5 \%$ of $\mathrm{O}_{2}+20 \% \mathrm{CO}_{2}+75 \% \mathrm{~N}_{2}$ showed low influence in the physicatchemical and sensorial characteristics. It was found that the gaseous mixture (independent of the packaging) restricted the microorganisms growth while control showed high mesophilics bacteria count after the $9^{\text {th }}$ day. 


\section{INTRODUÇÃO}

A mudança dos hábitos alimentares da sociedade moderna, que busca cada vez mais produtos com qualidade e conveniência, tem levado a uma nova tecnologia de alimentos - processamento mínimo de frutas e hortaliças. Esta tecnologia tem como objetivo fornecer ao consumidor um produto fresco e com grande conveniência, ou seja, sem cascas ou sementes e em porções individuais.

Há muitas definições para produtos minimamente processados, porém, podemos considerar como qualquer fruta, hortaliça, ou combinação destas, que tenha sido alterada fisicamente, mas que permaneça em estado fresco.

O processamento mínimo é uma tecnologia inovadora, símbolo da economia de tempo e da conveniência. Proporciona agregação de valor ao produto agrícola, aumentando a competitividade do setor de produção e possibilitando meios alternativo s de comercialização (Chitarra, 1998).

As operações envolvidas no processamento mínimo de frutas e hortaliças, reduzem a vida útil das mesmas (Cantwell, 1992). O corte dos tecidos leva ao aumento da taxa respiratória e produção de etileno, com conseqüente aceleração do processo de senescência. Além disso, os exsudados destes cortes são um meio favorável para o crescimento de fungos e bactérias (Burns, 1995).

Para controlar ou minimizar estas conseqüências negativas, o controle da temperatura é uma das técnicas mais importantes, por reduzir a respiração e produção de etileno, retardar o crescimento microbiano e reduzir as deteriorações, como o escurecimento e o amaciamento no produto minimamente processado (Brecht, 1995; Cantwell, 2000). Outra alternativa é a tecnologia de atmosfera modificada. A modificação da atmosfera no interior da embalagem com frutas e hortaliças 
minimamente processadas pode ser obtida passivamente através da respiração do produto ou ativamente pela injeção de mistura gasosa na embalagem (Sarantópoulos et al., 1998).

Atmosferas com 2 a $8 \% \mathrm{O}_{2}$ e 5 a $15 \% \mathrm{CO}_{2}$ têm potencial para aumentar a vida útil de frutas e hortaliças minimamente processadas, embora para cada fruta e hortaliça exista uma atmosfera específica que maximiza sua durabilidade (Cantwell, 1992).

O melão é uma das frutas bastante promissoras para a obtenção de produtos minimamente processados, dada sua grande aceitação pelos consumidores, mas o conhecimento sobre os aspectos microbiológicos, fisiológicos e nutricionais ainda é pequeno (Durigan \& Sargent, 1999). Diante deste fato, este trabalho teve como objetivos determinar o tipo de corte, a temperatura de armazenamento e os materiais de embalagem que proporcionam melhor manutenção da qualidade de melões minimamente processados. Deste modo, espera-se elaborar um produto prático, com qualidade sensorial e nutricional que atenda às necessidades do consumidor, além de fornecer uma alternativa para o produtor agregar valor ao seu produto agrícola. 


\section{REVISÃO DE LITERATURA}

\subsection{Aspectos gerais da cultura do melão}

O meloeiro pertence à família Cucurbitaceae, ao gênero Cucumis e à espécie Cucumis melo L. Sua origem ainda não está bem definida. Alguns autores acreditam que seja originário da África tropical enquanto outros acreditam ser do oeste da Ásia. (Zapata et al., 1989).

Segundo Araújo (1980), o meloeiro é uma planta anual e seus frutos são bastante variados tanto em relação ao tamanho (podem ter de $100 \mathrm{~g}$ até vários quilogramas), como com relação ao formato (achatado, redondo ou cilíndrico). A casca pode ser lisa, ondulada ou rendilhada e de várias cores (branca, preta, amarela, verde, marrom). A polpa pode se apresentar crocante ou dissolvente, e de coloração branca, verde, salmão ou vermelha. Pode apresentar aroma característico, que está diretamente relacionado à coloração da polpa, que quanto mais avermelhada, maior a intensidade do cheiro.

Atualmente, os principais melões produzidos comercialmente pertencem a dois grupos: Cucumis melo inodorus Naud. e Cucumis melo cantaloupensis Naud., que correspondem, respectivamente, aos melões inodoros e aromáticos (Alves, 2000).

Os plantios de melões estão espalhados por todas as regiões do Brasil, sendo que a região nordeste é a maior produtora de melão no país. No período de 1992 a 1999, a produção de melão amarelo nesta região atingiu 131.702.000 frutos em uma área de 10.038 ha (FNP, 2002).

O "net-melon", largamente cultivado no Japão, foi introduzido no Brasil por volta de 1990. Pertence ao grupo Cucumis melo cantaloupensis Naudin e 
apresenta tamanho idêntico ao melão amarelo, diferenciando-se pela casca rendilhada e alto teor de açúcar. No Brasil, tem sido cultivado na região Nordeste, principalmente no pólo Mossoró-Açú. Produtores do município de Assaí (Paraná), Capão Bonito e Pilar do Sul (São Paulo) também tem produzindo este melão com sucesso (Rostelato, 1997; Alves, 2000).

O "net-melon" é conhecido no mundo todo como melão nobre, tendo excelente aceitação no mercado europeu e asiático, sendo de fácil comercialização nas classes econômicas A e B do Brasil (Brandão Filho \& Vasconcellos, 1998).

O ponto correto de colheita é de fundamental importância para que os frutos apresentem qualidade elevada. Caso a colheita ocorra antes do tempo ideal, este fruto terá sua qualidade interna bastante prejudicada, principalmente em relação ao teor de sólidos solúveis totais, ou seja, ter-se-á um fruto com aparência boa e sem sabor (Brandão Filho \& Vasconcelos, 1998).

Para determinação do ponto de colheita, deve-se observar algumas características como teores de sólidos solúveis totais, firmeza da polpa, cor e aspecto da casca. Somente quando estas características estiverem de acordo com os requisitos mínimos de qualidade estabelecidos, é que a colheita pode ser realizada (Alves, 2000).

A qualidade final do produto na época de colheita e após a colheita está relacionada com numerosos fatores, principalmente o manejo da cultura (Chitarra \& Chitarra, 1990).

O melão rendilhado cultivado em ambiente protegido, quando bem conduzido, apresenta-se com excelente qualidade, proporcionando preços elevados (Brandão Filho \& Vasconcelos, 1998) e quando processado e oferecido ao consumidor de modo prático, certamente terá maior valor agregado.

\subsection{Fisiologia pós-colheita do melão}

Os melões Honeydew e Cantaloupe são classificados por Kader (1992) como frutos que apresentam baixa e moderada taxa respiratória (5-10 mg. $\mathrm{CO}_{2} \cdot \mathrm{Kg}^{-1} \cdot \mathrm{h}^{-1} \mathrm{e}$ 10-20 $\mathrm{mg} \cdot \mathrm{Kg}^{-1} \cdot \mathrm{h}^{-1}$ a $\left.5^{\circ} \mathrm{C}\right)$, respectivamente. O mesmo autor classifica os melões como sendo 
climatéricos, ou seja, após colhidos estes frutos têm aumento na atividade metabólica paralelamente com aumento da taxa respiratória.

A redução da atividade metabólica pode ser obtida através do armazenamento refrigerado, embora o uso da refrigeração para melão apresenta alguns problemas em função da sua suscetibilidade a danos pelo frio. Os danos pelo frio manifestam-se por amadurecimento anormal (falta de aroma, acompanhado pelo aparecimento de manchas escuras na casca) e dependem da cultivar (Alves,2000). Contudo, deve-se considerar os limites de temperatura tolerados para cada cultivar.

Em melão não há aumento do conteúdo de açúcar após a colheita (Avakian, 20 out.2001), ao contrário de frutos climatéricos como banana e maçã que armazenam apreciáveis quantidades de amido para conversão em açúcares solúveis durante o armazenamento (Brady, 1987).

Segundo Bleinroth (1994), a textura da polpa de melão é dada pela protopectina, composto péctico, parcialmente insolúvel, localizado na lamela média das células adjacentes e na parede primária, sendo que à medida que a maturação progride a protopectina vai sendo convertida em compostos solúveis.

No entanto, Menezes et al. (1995), verificou estabilidade destes compostos pécticos durante o armazenamento de melão amarelo 'Agroflora 646'. Estes autores sugerem que o amolecimento de melão pode estar relacionado com outros processos, tais como, a perda da integridade da membrana das células mesocárpicas e rompimento das interações iônicas entre polímeros da parede celular.

\subsection{Aspectos gerais do processamento mínimo de frutas e hortaliças}

As operações envolvidas no processamento mínimo incluem seleção, lavagem, descascamento e corte visando obter um produto fresco, conveniente, que possa ser preparado e consumido em menos tempo (Burns, 1995).

Hortifrutícolas minimamente processados vêm ganhando uma proporção significativa do mercado de frutas e hortaliças in natura, desde a sua introdução nos 
canais de distribuição dos EUA, cerca de 30 anos atrás; e na França, no início da década de 80. Em 1997, a venda de produtos minimamente processados nos EUA alcançou US\$ 7,9 bilhões, prevendo-se um crescimento para US\$ 19 bilhões até 2003 (FNP, 2000).

No Brasil, a utilização destes produtos é recente, tendo iniciado no fim dos anos 80. Todavia, tem se observado um crescimento espantoso nos últimos anos. Calcula-se que no ano de 1998, o setor tenha movimentado 450 milhões de reais. Somente na grande São Paulo, nos últimos 3 anos, verificourse um aumento de $200 \%$ no volume de produtos minimamente processados comercializados no varejo (Moretti, 1999).

Hortaliças minimamente processadas são muito mais perecíveis do que quando intactas, porque são submetidas a severos estresses físicos advindos principalmente do descascamento e corte. Estes danos mecânicos aumentam o metabolismo dos produtos, com o consequente aumento da taxa de respiração (Rosen \& Kader, 1989).

Desse modo, devido à alta perecibilidade das frutas e hortaliças minimamente processadas os fatores temperatura, atmosfera modificada, umidade relativa, aspectos fisiológicos, bioquímicos e microbiológicos devem ser observados

\subsubsection{Efeito da temperatura}

Temperaturas baixas reduzem o metabolismo e a taxa de respiração de frutas e hortaliças, além de retardarem outros processos fisiológicos, bioquímicos e microbiológicos, causadores da deterioração (Chitarra \& Chitarra, 1990). Em produtos minimamente processados, o controle da temperatura é uma das principais técnicas utilizadas para minimizar o efeito do corte. A temperatura da sala de processamento e da água de sanitização devem ser próximas de $0^{\circ} \mathrm{C}$, a fim de reduzir a taxa respiratória, produção de etileno, bem como outras reações associadas à senescência.

A recomendação para o armazenamento de produtos minimamente processados é $0^{\circ} \mathrm{C}$, mesmo para produtos com sensibilidade à injúria pelo frio, pois usualmente os produtos são consumidos sem serem transferidos para temperaturas elevadas, condição que favorece o aparecimento dos sintomas de injúria pelo frio. No entanto, para 
melancia minimamente processada, armazenamento em temperatura de $2-3^{\circ} \mathrm{C}$ pode resultar em melhor vida de prateleira do que armazenamento a $0^{\circ} \mathrm{C}$ (Cantwell, 2000).

Allong et al. (2000) verificaram que a temperatura de $5^{\circ} \mathrm{C}$ foi mais eficiente que $10^{\circ} \mathrm{C}$ em retardar o crescimento microbiano e preservar a qualidade sensorial de mangas minimamente processadas. Estes benefícios da baixa temperatura, também foram observados por Portela et al. (1997) em melões Cantaloupe cv. Durango minimamente processados.

\subsubsection{Importância da atmosfera modificada}

O processamento mínimo torna as frutas e hortaliças mais perecíveis do que antes da higienização e corte. Portanto, na comercialização destes produtos, a embalagem é um requisito essencial para a manutenção da qualidade.

O sistema com atmosfera modificada mais utilizado consiste no acondicionamento do produto hortícola em uma embalagem selada e permeável a gases, a fim de reduzir as concentrações de $\mathrm{O}_{2}$ e aumentar as concentrações de $\mathrm{CO}_{2}$ (Zagory \& Kader, 1988). A magnitude das alterações nas concentrações de gases depende da natureza e espessura do material de embalagem, da taxa respiratória do produto, da relação entre a quantidade de produto e a área superficial do material de embalagem e da temperatura de armazenamento (Smith et al., 1987).

A atmosfera modificada pode ser criada de forma passiva ou ativa. No caso da atmosfera modificada passiva, o produto é acondicionado em embalagem e a atmosfera é modificada pela própria respiração do produto. A atmosfera modificada ativa é criada injetando-se no espaço livre da embalagem uma mistura gasosa pré-determinada (Yam \& Lee, 1995; Hotchkiss, 1995). Uma das vantagens da atmosfera modificada ativa é permitir a rápida estabilização da atmosfera desejada (Zagory \& Kader, 1988).

Atmosferas com 2 a $8 \%$ de $\mathrm{O}_{2}$ e 5 a $15 \%$ de $\mathrm{CO}_{2}$ têm potencial para preservar a qualidade de frutas e hortaliças minimamente processadas, embora, para cada vegetal exista uma atmosfera específica que maximiza sua durabilidade (Cantwell, 1992). Kader 
\& $\mathrm{Ke}$ (1994) observaram que o mínimo de $\mathrm{O}_{2}$ e máximo de $\mathrm{CO}_{2}$ tolerado pelo melão Cantaloupe é de $2 \%$ e $15 \%$, respectivamente.

Bai et al. (2001) observaram que a atmosfera modificada mantém a qualidade de melões cantaloupes cv. Athena minimamente processado e que a injeção de $4 \% \mathrm{O}_{2}+$ $10 \% \mathrm{CO}_{2}$ foi mais eficiente que a modificação passiva da atmosfera em reter a coloração, reduzir a taxa respiratória e a microbiota dos melões.

Portela \& Cantwell et al. (1998) observaram que pedaços de melões Honeydew armazenados no ar e em atmosfera controlada $\left(15 \% \mathrm{CO}_{2}\right)$ apresentaram boa a muito boa qualidade visual total, respectivamente, até o $6^{\circ}$ dia. $\mathrm{O}$ decréscimo na qualidade foi devido à falta de aparência de produto fresco, com pequeno ressecamento da superfície.

A utilização de filmes poliméricos ou outros materiais de embalagens, como embalagens semi-rígidas devem promover uma atmosfera de $\mathrm{O}_{2}$ e $\mathrm{CO}_{2}$ que resulte em redução da respiração sem induzir processos de anaerobiose (Wiley, 1994).

Dentre os materiais de embalagens, o polietileno é o polímero mais utilizado na embalagem de alimentos em geral. Tem a mais simples composição química de todos os polímeros e geralmente o menor custo. Pode ser classificado como polietileno de baixa densidade quando esta propriedade varia de 0,915 a $0,939 \mathrm{~g} . \mathrm{cm}^{-3}$, e o polietileno de alta densidade, quando esta é de $0,940 \mathrm{~g} \cdot \mathrm{cm}^{-3}$ ou mais. O polietileno de baixa densidade é um material bastante flexível e resistente à impacto. Possui alta permeabilidade ao vapor d'água, quando comparado aos demais filmes plásticos. É muito utilizado na embalagem de alimentos, porém, ge ralmente constitui-se em barreira muito intensa ao $\mathrm{O}_{2} \mathrm{e} \mathrm{CO}_{2}$ na embalagem de frutas e hortaliças que possuem alta taxa respiratória (Yam et al., 1992).

$\mathrm{Na}$ linha de filmes poliolefínicos co-extrusados, têm sido desenvolvidos alguns materiais de alta permeabilidade a gases, FAMÍLIA PD-900, específicos para manter a correta atmosfera modificada de vegetais pré-processados, mantidos sob refrigeração. As taxas de permeabilidade ao oxigênio destes filmes variam de 3.500 a $16.500 \mathrm{~cm}^{3} \cdot \mathrm{m}^{-2} \cdot \mathrm{dia}^{-1} \mathrm{e}$ os sacos podem apresentar opções de aplicação de anti-fog. (Cryovac Division, 1994).

A correta especificação da embalagem para frutas e hortaliças requer otimização de parâmetros físicos, químicos, bioquímicos e ambientais, sendo portanto um problema complexo, cuja solução envolve testes experimentais (Sarantópoulos et al., 1998). 


\subsubsection{Efeito da umidade relativa}

A perda de água é também uma das principais causas de deterioração de frutas e hortaliças após a colheita, por produzir o amarelecimento e o enrugamento de seus tecidos. Hortaliças minimamente processadas apresentam maior relação superfície/volume do que quando inteiras, facilitando ainda mais a perda de água de seus tecidos (Tatsumi et al., 1991).

\subsubsection{Aspectos fisiológicos e bioquímicos}

O estresse causado pelo processamento resulta em aumento da respiração e produção de etileno, aumentando atividade de enzimas responsáveis pelo escurecimento, desenvolvimento de sabores e odores desagradáveis e amaciamento dos tecidos (Wiley, 1994; Cantwell, 1992).

A reação enzimática envolvida no escurecimento dos tecidos depende do $\mathrm{pH}$. Uma redução de 0,5 no pH natural de maçãs resultou no decréscimo de $50 \%$ da atividade da polifenolixidase.

As modificações bioquímicas do aroma e sabor são decorrentes das peroxidações enzimáticas catalizadas por lipoxigenases, levando à formação de aldeídos e cetonas (Hildebrand, 1989).

De acordo com Varoquaux et al. (1990), a perda de firmeza dos tecidos de fatias de kiwi é devido à hidrólise de componentes da parede celular. O mecanismo da hidrólise dos componentes da parede celular depois do corte difere daquele envolvido no amadurecimento normal do fruto, onde predomina o processo de solubilização da protopectina. $\mathrm{O}$ mesmo autor relata que fatias de kiwi à $2^{\circ} \mathrm{C}$ perderam $50 \%$ da firmeza inicial em um período menor que 2 dias. 


\subsubsection{Microrganismos}

O processamento mínimo favorece a contaminação de alimentos por microrganismos deterioradores e patogênicos, em razão do manuseio e do aumento das injúrias nos tecidos (Wiley, 1994).

Ngwyen \& Carlin (1994) afirmam que um grande número de microrganismos tem sido encontrado em produtos minimamente processados, incluindo leveduras, coliformes, coliformes fecais, microbiotas mesofílicas e pectinolíticas, bolores, etc.

A contagem dos microorganismos mesófilos aeróbios permite avaliar as condições microbiológicas de processamento do alimento. Números elevados normalmente diminuem seu tempo de vida útil (Hajdenwurcel, 1998).

O número de coliformes encontrados por diferentes autores em cenoura, chicória e repolho minimamente processado na forma de 'tiras' e armazenado à $8^{\circ} \mathrm{C}$ por 1 dia situou-se na faixa de $10^{4}-10^{5}$ UFC. Barriga et al. (1991) encontrou uma relação linear entre o número de microorganismos em alface minimamente processada em tiras e o decréscimo na qualidade visual, durante o armazenamento.

Cubos de melancia armazenados a $5^{\circ} \mathrm{C}$ em $5 \% \mathrm{O}_{2}+10 \% \mathrm{CO}_{2}$ apresentaram após 15 dias contagem microbiana equivalente ao valor inicial, enquanto cubos armazenados sem atmosfera controlada desenvolveram um número excessivo de microrganismos (Sargent, 1999).

Segundo Hiraushi \& Horie (1982), os coliformes são bons indicadores de contaminação fecal em alimentos. De acordo com a "International Commission on Microbiological Specifications for Foods - ICMSF"(1978), a presença de coliformes em

alimentos indica manipulação inadequada durante o processamento, uso de equipamentos em más condições sanitárias ou ainda utilização de matéria-prima contaminada.

Dessa forma, torna-se importante a sanitização de toda planta de processamento inclusive dos instrumentos e equipamentos utilizados, bem como a utilização de luvas, máscaras, aventais e botas por parte dos operadores, o uso de água clorada para a 
lavagem dos vegetais, controle rigoroso da temperatura e utilização de matéria-prima de qualidade.

Ngwyen \& Carlin (1994), afirmam que um bom controle da temperatura de armazenamento, uso de atmosfera modificada e desinfecção química diminuem consideravelmente o desenvolvimento destes microorganismos.

\subsubsection{Influência do tipo de corte}

A utilização de instrumentos de corte bem afiados é importante para a obtenção de produtos de alta qualidade. Instrumentos sem corte causam maiores danos mecânicos aos produtos, reduzindo sua vida útil. A direção do corte também influencia a vida útil. A durabilidade de pimentão e cenoura cortados no sentido transversal (em rodelas) é maior quando comparada com o corte longitudinal (tipo palito) (Luengo \& Lana, 1997). 


\section{TEMPERATURA DE ARMAZENAMENTO E TIPO DE CORTE PARA MELÃO MINIMAMENTE PROCESSADO}

\section{RESUMO}

O presente trabalho teve como objetivo determinar a temperatura de armazenamento e o tipo de corte que proporciona melhor manutenção da qualidade de melão minimamente processado. Melões rendilhados cv. Bonus II foram processados em câmara fria a $12^{\circ} \mathrm{C}$. Os frutos foram cortados manualmente em 8 fatias longitudinais. Em um dos tratamentos as fatias foram divididas em pedaços de aproximadamente $3 \mathrm{~cm}$ de base e no outro tratamento foram utilizadas fatias inteiras. O produto minimamente processado foi acondicionado em bandejas de polietileno rígida e armazenados a $3^{\circ}, 6^{\circ} \mathrm{e}$ $9^{\circ} \mathrm{C}$. Foram realizadas análises físico-químicas e sensoriais a cada 3 dias por um período de 9 dias. A coloração e o teor de sólidos solúveis totais não foram afetados pelos tratamentos. $\mathrm{O}$ produto armazenado a $3^{\circ} \mathrm{C}$ apresentou maior eficiência na manutenção da firmeza e das características sensoriais, independente do tipo de corte. Os melões armazenados a $9^{\circ} \mathrm{C}$ apresentaram decréscimo nos valores de $\mathrm{pH}$ e aumento da acidez total titulável. A aparência foi considerada boa até o $9^{\circ}$ dia de armazenamento e o aroma até o $6^{\circ}$ dia, para melões a $3^{\circ} \mathrm{C}$. Em todos os tratamentos houve declínio do sabor durante o armazenamento. Pelos resultados obtidos conclui-se que a qualidade de melões minimamente processados pode ser mantida por 6 dias a $3^{\circ} \mathrm{C}$, independente do tipo de corte.

Palavras-chave: Cucumis melo L., processamento mínimo, qualidade, armazenamento refrigerado. 


\section{STORAGE TEMPERATURE AND CUT TYPE FOR MINIMALLY PROCESSED MELON}

\section{SUMMARY}

The objective of this work was to determine the storage temperature and the cut type for better quality maintenance minimally processed melons (Cucumis melo L. var. reticulatus cv. Bonus II). Fruits were hand cut in 8 longitudinal slices in cold chamber at $12^{\circ} \mathrm{C}$. The treatment slice were divided in $3 \mathrm{~cm}$ pieces and the other treatment whole slices were used. The product minimally processed was packed in rigid polyethylene terephthalate tray and stored at 3,6 and $9^{\circ} \mathrm{C}$. Physicatchemical and sensorial characteristics were analyzed each 3 days during 9 days. The coloration and total soluble solids were not affected by the treatments. The product stored at $3^{\circ} \mathrm{C}$ had higher efficiency, maintaining firmness and sensorial characteristics, independent of the cut type. The melons stored at $9^{\circ} \mathrm{C}$ showed increasing in total acidity and $\mathrm{pH}$ reduction. The appearance was considered good until 9 days of storage and the aroma until 6 days, for melons at $3^{\circ} \mathrm{C}$. The flavor declined during the storage for all treatments. Minimally processed melons quality can be maintained until 6 days at $3^{\circ} \mathrm{C}$, independent of the cut type.

Key-words : Cucumis melo L., fresh-cut, quality, cold storage.

\subsection{Introdução}

O processamento mínimo inclui operações de seleção, lavagem, descascamento e corte, visando obter um produto fresco e conveniente para o preparo e consumo (Burns, 1995).

Nos EUA, a venda de produtos minimamente processados alcançou US\$7,9 bilhões em 1997, prevendo-se crescimento para US\$ 19 bilhões até 2003. No Brasil, o setor movimentou R\$ 450 milhões em 1998 (FNP, 2000). É uma atividade que está em 
expansão, devido a necessidade que os consumidores têm de adquirir produtos com qualidade e praticidade (Wiley, 1994).

Hortaliças e frutas minimamente processadas são mais perecíveis do que quando inteiras, porque são submetidas a severos estresses físicos advindos principalmente do descascamento e corte. O efeito do corte leva a um aumento da taxa respiratória e produção de etileno, com aumento da atividade de enzimas que atuam em reações específicas (Chitarra, 1998).

As mudanças bioquímicas em frutas e hortaliças minimamente processados, são, em parte, consequiência do efeito da temperatura na atividade enzimática. Em temperaturas maiores que $10^{\circ} \mathrm{C}$, a concentração de $\mathrm{CO}_{2}$ aumenta abruptamente devido a intensificação do metabolismo e proliferação microbiana (Wiley, 1994).

O controle da temperatura é uma das técnicas mais usuais e importantes para minimizar o efeito do corte em frutas e hortaliças (Brecht, 1995). Allong et al. (2000) verificaram que a temperatura de $5^{\circ} \mathrm{C}$ foi mais eficiente que $10^{\circ} \mathrm{C}$ em retardar o crescimento microbiano e preservar a qualidade sensorial de mangas minimamente processadas. O objetivo deste trabalho foi determinar a temperatura de armazenamento e tipo de corte que proporcione melhor manutenção da qualidade de melão minimamente processado.

\subsection{Material e Métodos}

Melões rendilhados cv. Bônus II provenientes do Rio Grande do Norte foram obtidos na Ceasa-Campinas e levados ao Laboratório de Pós-Colheita do Departamento de Produção Vegetal da Esalq/USP, onde foram selecionados quanto à ausência de danos mecânicos e grau de maturação. Utilizaram-se frutos com aproximadamente 1,2 $\mathrm{Kg}$. Estes foram lavados com detergente a fim de retirar as sujidades mais grosseiras, sendo em seguida imersos em solução de hipoclorito de sódio a 100 ppm por 10 minutos para evitar contaminação durante o corte. 
Terminado esta etapa os melões permaneceram por 12 horas em câmara fria a $10^{\circ} \mathrm{C}$ e a seguir foram submetidos ao processamento, cujas etapas estão descritas abaixo e ilustradas na Figura 3.

a) Corte: Os melões foram cortados ao meio e as sementes retiradas com auxílio de uma colher. Cada metade foi cortada em 4 fatias longitudinais e em seguida as cascas foram eliminadas. Em um dos tratamentos as fatias foram divididas em pedaços menores com aproximadamente $3 \mathrm{~cm}$ de base (Figura 1) e no outro tratamento foram utilizadas as fatias inteiras (Figura 2). Este procedimento foi feito a $12^{\circ} \mathrm{C}$, sob condições higiênicas.

b) Desinfecção: O fruto cortado foi imerso em solução de hipoclorito de sódio a 100 ppm por 3 segundos, com objetivo de reduzir riscos de contaminação.

c) Eliminação do excesso de água: Os pedaços de melões foram drenados por aproximadamente 1 minuto em um escorredor doméstico, devidamente higienizado.

d) Embalagem: Após retirada do excesso de água, os pedaços de melões foram distribuídos em bandejas de poliestireno rígida, com aproximadamente $240 \mathrm{~g}$ de melão, o que correspondia a 2 fatias ou 8 -10 cubos.

Após o processamento os melões foram armazenados a 3,6 e $9^{\circ} \mathrm{C}$ com a finalidade de verificar a temperatura ideal que mantém as características originais do produto.

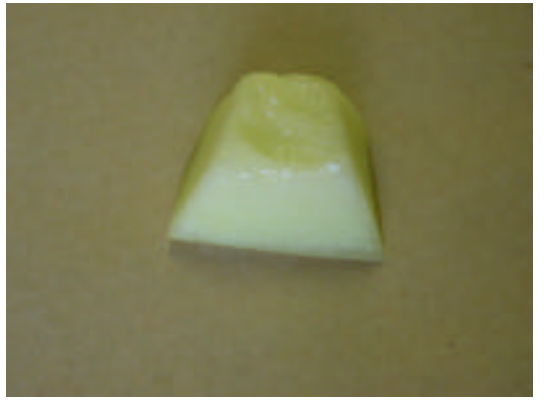

Figura 1- Caracterização do corte em cubo.

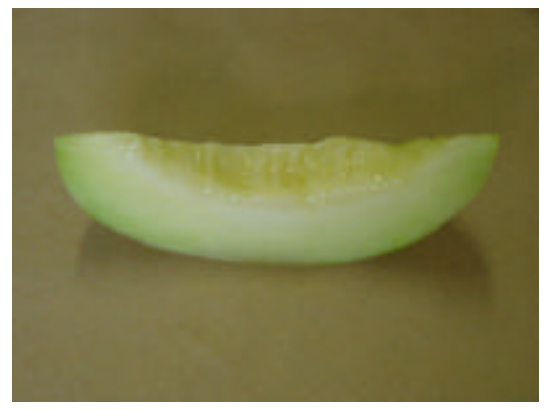

Figura 2- Caracterização do corte em fatia. 

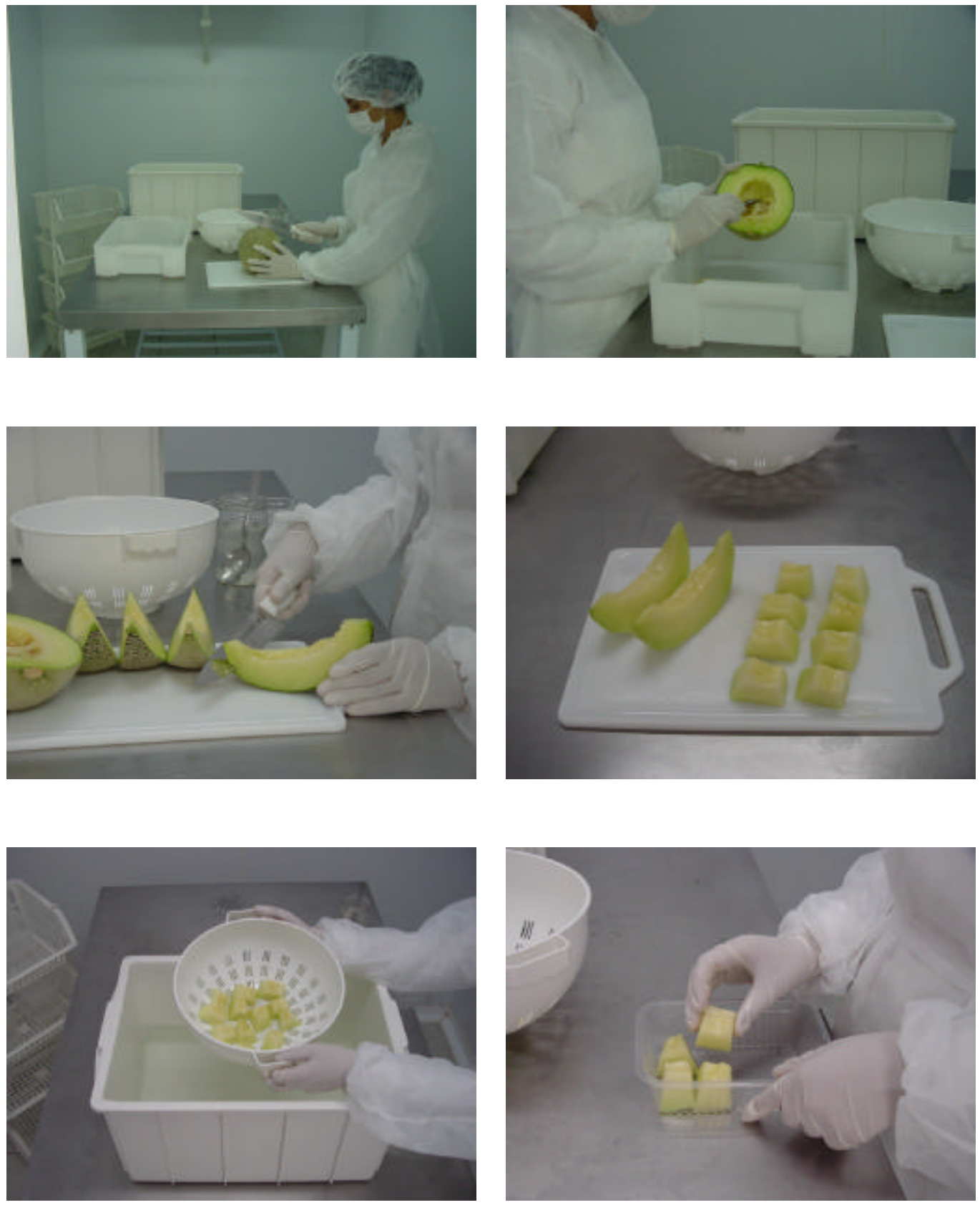

Figura 3 - Seqüência do processamento mínimo de melão. 
As análises físico-químicas foram realizadas a cada 3 dias por um período de 9 dias, quanto à:

a) Escurecimento: Determinada com colorímetro Minolta, modelo CR-300, tomando-se uma leitura na região placentária do cubo e duas leituras na região placentária da fatia. As leituras foram realizadas em seis cubos e duas fatias por repetição e os resultados expressos em Luminosidade $\left(\mathrm{L}^{*}\right)$.

b) Firmeza da polpa: Determinada com auxílio de penetrômetro digital, ponteira $8 \mathrm{~mm}$, tomando se uma leitura na região palcentária do cubo e da fatia. As leituras foram realizadas em seis cubos e em duas fatias por repetição, sendo os resultados expressos em Newton $(\mathrm{N})$.

c) Teor de Sólidos Solúveis Totais (SST): Leitura direta em refratômetro digital Atago modelo Palete 101, utilizando-se polpa homogeneizada em triturador doméstico tipo 'mixer'. Os resultados foram expressos em ${ }^{\circ}$ Brix.

d) $\mathrm{pH}$ : Leitura em solução de polpa homogeneizada, com pHmetro marca Tecnal.

A avaliação sensorial (aparência, aroma e sabor) foi realizada por uma equipe de 5 provadores utilizando uma escala de notas, onde: 5=ótimo; 4=bom; 3=regular; 2=ruim e 1=péssimo. A nota 3 foi considerada como limite de aceitabilidade. Os pedaços de melão foram oferecidos aos provadores depois de mantidos por $3 \mathrm{~h}$ sob temperatura ambiente.

A descrição das notas encontra-se a seguir:

Aparência: $5=$ melão com aspecto de frescor, ausência de escurecimento, translucência e bolores; 4= melão com aspecto de frescor, porém com leve escurecimento na região placentária e/ou leve translucência e ausência de bolores; 3= melão com pouco aspecto de frescor, moderado escurecimento na região placentária e/ou moderada translucência e ausência de bolores; $2=$ melão sem aspecto de frescor, elevado escurecimento na região placentária e/ou elevado grau de translucência e ausência de bolores; $1=$ melão com elevado grau de translucência e bolores. 
Aroma: 5= melão bastante aromático (típico de net melon); 4= melão com aroma moderado; 3= melão com aroma fraco ou sem aroma; 2= melão com aroma alcoólico; $1=$ melão com aroma de produto putrefado.

Sabor: $5=$ sabor característico; $4=$ leve perda do sabor característico; $3=$ ausência de sabor característico; 2 = sabor levemente alcoólico; $1=$ sabor alcoólico.

O delineamento experimental utilizado foi inteiramente ao acaso em esquema fatorial 2x3x4 (2 tipos de corte, 3 temperaturas de armazenamento e 4 períodos de avaliação). Utilizaram-se 5 repetições, sendo cada uma representada por uma bandeja contendo aproximadamente $240 \mathrm{~g}$ do produto minimamente processado. Os resultados foram submetidos à análise de variância pelo teste $\mathrm{F}$ e comparação de médias pelo teste Tukey $(5 \%)$.

\subsection{Resultados e Discussão}

Observa-se pela Tabela 1 que houve redução nos valores de Luminosidade (L) nas três temperaturas de armazenamento, sendo a mudança de coloração significativa apenas no decorrer do período de armazenamento, ou seja, não houve efeito de corte nem temperatura. A variável L indica luminosidade, diferenciando cores claras de escuras. Seu valor varia de zero para cores escuras a 100 para cores claras. Desta forma, verificou-se que houve escurecimento da polpa do melão durante o armazenamento, o qual ocorreu de forma linear com o tempo de armazenamento (Figura 4). 
Tabela 1. Escurecimento da polpa de melão rendilhado minimamente processado durante o armazenamento refrigerado ${ }^{1,2)}$

\begin{tabular}{ccccc}
\hline $\begin{array}{r}\text { Temperatura de } \\
\text { Armazenamento }\end{array}$ & $\mathbf{0}$ & \multicolumn{4}{c}{ Dias de armazenamento } \\
& --10 & $\mathbf{3}$ & $\mathbf{6}$ \\
\hline $3^{\circ} \mathrm{C}$ & $49,12 \mathrm{~A}$ & $46,11 \mathrm{AB}$ & $47,96 \mathrm{~A}$ & $41,76 \mathrm{~B}$ \\
$6^{\circ} \mathrm{C}$ & $49,12 \mathrm{~A}$ & $44,71 \mathrm{AB}$ & $45,40 \mathrm{AB}$ & $42,48 \mathrm{~B}$ \\
$9^{\circ} \mathrm{C}$ & $49,12 \mathrm{~A}$ & $46,45 \mathrm{~A}$ & $44,22 \mathrm{AB}$ & $40,53 \mathrm{~B}$ \\
Médias & $49,12 \mathrm{~A}$ & $45,76 \mathrm{~B}$ & $45,86 \mathrm{~B}$ & $41,59 \mathrm{C}$ \\
\hline
\end{tabular}

CV (\%): 10,31

${ }^{1)}$ Médias seguidas de mesma letra maiúscula na linha não diferem entre si, pelo teste de Tukey ao nível de $5 \%$ de probabilidade.

${ }^{2)}$ Os valores são referentes à média de coloração obtid a entre os dois tipos de corte.

A mudança de coloração durante o período de armazenamento caracterizourse por um leve escurecimento na região placentária. Em frutas e hortaliças minimamente processadas, existem vários tipos de reações oxidativas, as quais causam escurecimento do tecido (Wiley, 1994). O uso de aditivos para preservação da coloração de produtos minimamente processados tem sido alvo de estudo para muitos pesquisadores. Lamikanra \& Watson (2000) verificaram que a utilização de ácido ascórbico preservou a coloração de melão Cantaloupe minimamente processado por 25 dias a $4^{\circ} \mathrm{C}$. 


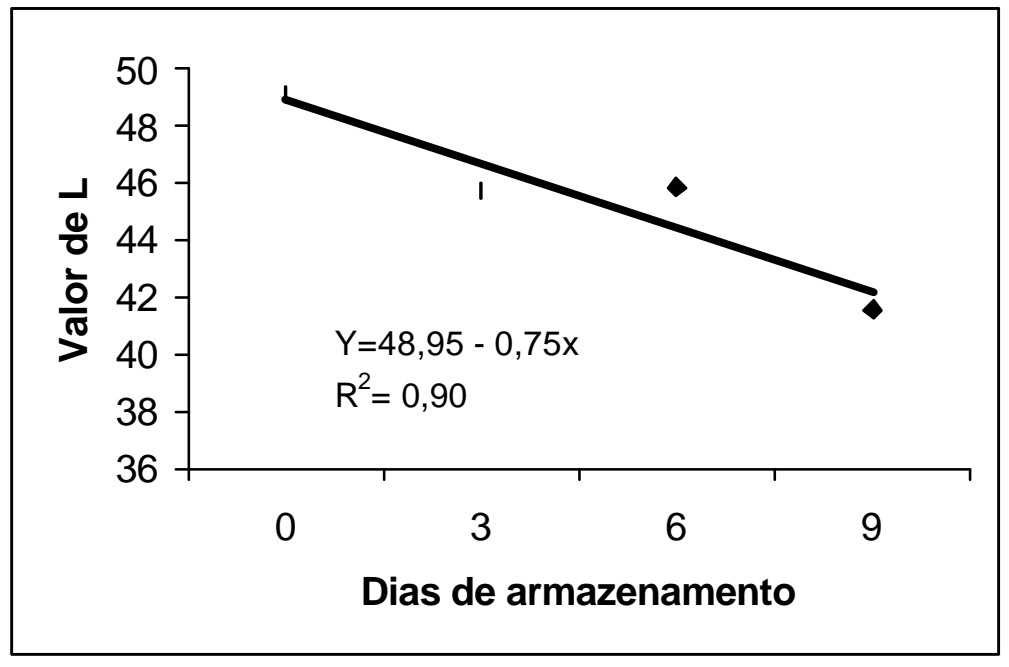

Figura 4 - Escurecimento da polpa de melão rendilhado minimamente processado durante o armazenamento refrigerado. Os valores representam a média de 2 tipos de corte cubo e fatia) e 3 temperaturas de armazenamento $\left(3,6\right.$ e $\left.9^{\circ} \mathrm{C}\right)$.

Verifica-se na Tabela 2 uma redução significativa da firmeza da polpa de melão minimamente processado, com o aumento do tempo e da temperatura de armazenamento. Ao final de 9 dias de armazenamento a firmeza da polpa dos melões compreendia $79,3 \%, 54,3 \%$ e $49,2 \%$ da firmeza inicial, para o produto armazenado a 3 , 6 e $9^{\circ} \mathrm{C}$, respectivamente. Portela \& Cantwell (1998), verificaram um decréscimo de $28 \%$ da firmeza em pedaços de melão Cantaloupe armazenados a $5^{\circ} \mathrm{C}$ por 12 dias.

Verifica-se também na Tabela 2 que, em média, a firmeza da polpa dos melões armazenados a $3^{\circ} \mathrm{C}$ foi significativamente superior àqueles armazenados nas demais temperaturas.

Portela et al. (1997) citam a temperatura como fator mais importante para conservação de melão minimamente processado. Este autor observou que pedaços de melões mantidos a $5^{\circ} \mathrm{C}$ por 9 dias apresentaram maior firmeza do que a $10^{\circ} \mathrm{C}$. 
Tabela 2. Firmeza da polpa de melão rendilhado minimamente processado durante o armaze namento refrigerado ${ }^{1,2)}$

\begin{tabular}{|c|c|c|c|c|c|}
\hline \multirow{2}{*}{$\begin{array}{l}\text { Temperatura de } \\
\text { Armazenamento }\end{array}$} & \multicolumn{5}{|c|}{ Dias de armazenamento } \\
\hline & 0 & 3 & 6 & 9 & Médias \\
\hline \multicolumn{6}{|c|}{--1- } \\
\hline $3^{\circ} \mathrm{C}$ & $4,46 \mathrm{a} A$ & $4,22 \mathrm{a} A B$ & 4,03a $\mathrm{AB}$ & 3,49a B & $4,05 \mathrm{a}$ \\
\hline $6^{\circ} \mathrm{C}$ & $4,46 \mathrm{a} A$ & $3,70 \mathrm{a} A$ & $3,52 \mathrm{a} \mathrm{A}$ & $2,42 \mathrm{~b} \mathrm{~B}$ & $3,52 \mathrm{~b}$ \\
\hline $9^{\circ} \mathrm{C}$ & 4,46a A & 3,37a B & 3,30a B & $2,19 b \mathrm{C}$ & $3,33 \mathrm{~b}$ \\
\hline Médias & $4,46 \mathrm{~A}$ & $3,76 \mathrm{~B}$ & $3,61 \mathrm{~B}$ & $2,70 \mathrm{C}$ & \\
\hline
\end{tabular}

$\mathrm{CV}(\%): 22,71$

${ }^{1)}$ Médias seguidas de mesma letra minúscula na coluna e maiúscula na linha não diferem entre si, pelo teste de Tukey ao nível de 5\% de probabilidade.

${ }^{2)}$ Os valores são referentes à média de firmeza obtida entre os dois tipos de corte.

O teor de sólidos solúveis totais apresentou interação significativa $(\mathrm{P}<0,05)$ entre os tipos de corte e o período de armazenamento. De maneira geral, houve um acréscimo no teor de sólidos solúveis totais durante o armazenamento (Tabela 3). Estes dados são discordantes daqueles obtidos por Shellie \& Saltveit (1993), os quais verificaram em melões reticulados comportamento constante do teor de sólidos solúveis totais durante todo período de armazenamento.

Os melões fatiados apresentaram a partir do $6^{\circ}$ dia de armazenamento valores significativamente maiores de sólidos solúveis totais em relação aos melões cortados na forma de cubos. Isto pode ser devido a um maior metabolismo dos melões cortados em cubos, o que levou a um maior consumo de reservas. 
Tabela 3. Teor de sólidos solúveis totais (SST) de melão rendilhado minimamente processado durante o armazenamento refrigerado ${ }^{1,2)}$

\begin{tabular}{|c|c|c|c|c|c|}
\hline \multirow[t]{2}{*}{ Tipo de corte } & \multicolumn{5}{|c|}{ Dias de armazenamento } \\
\hline & 0 & 3 & 6 & 9 & Médias \\
\hline & \multicolumn{5}{|c|}{ - SST ( ${ }^{\circ}$ Brix) } \\
\hline Fatia & $11,64 \mathrm{a} B$ & $12,10 \mathrm{a} A B$ & $12,45 \mathrm{a} A B$ & $13,10 \mathrm{a} \mathrm{A}$ & $12,32 \mathrm{a}$ \\
\hline Cubo & $11,64 \mathrm{a} A B$ & $12,24 \mathrm{a} \mathrm{A}$ & $11,20 \mathrm{~b} \mathrm{~B}$ & $12,11 \mathrm{~b} \mathrm{~A}$ & $11,80 \mathrm{~b}$ \\
\hline Média & $11,64 \mathrm{~A}$ & $12,17 \mathrm{AB}$ & $11,83 \mathrm{~B}$ & $12,70 \mathrm{~A}$ & \\
\hline \multicolumn{6}{|c|}{$\begin{array}{l}\text { CV(\%): } 8,08 \\
\text { 1) Médias seguidas de mesma letra minúscula na coluna e maiúscula na linha não diferem entre si, pelo } \\
\text { teste de Tukey ao nível de } 5 \% \text { de probabilidade. } \\
{ }^{2)} \text { Os valores são referentes à média de sólidos solúveis totais nas três temperaturas de armazenamento. }\end{array}$} \\
\hline \multicolumn{6}{|c|}{$\mathrm{Na}$ Tabela 4 verifica-se que o $\mathrm{pH}$ decresceu com o aumento da temperatura, } \\
\hline \multicolumn{6}{|c|}{$6^{\circ} \mathrm{C}$ e $9^{\circ} \mathrm{C}$. Relacionando os valores de acidez e pH (Tabela 4 e 5 ), verifica-se a partir do } \\
\hline \multirow{3}{*}{\multicolumn{6}{|c|}{$\begin{array}{l}3^{\circ} \text { dia, nos melões armazenados a } 9^{\circ} \mathrm{C} \text {, aumento nos valores de acidez e decréscimo nos } \\
\text { valores de } \mathrm{pH} \text {. Lamikanra et al. (2000) também observaram em melão minimamente } \\
\text { processado armazenado a } 20^{\circ} \mathrm{C} \text { decréscimo nos valores de } \mathrm{pH} \text { e aumento nos valores de }\end{array}$}} \\
\hline & & & & & \\
\hline & & & & & \\
\hline acidez total ti & Este & ribur & tòn & & 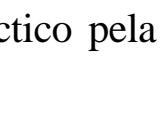 \\
\hline
\end{tabular}


Tabela 4. Médias de $\mathrm{pH}$ de melão rendilhado minimamente processado durante o armazenamento refrigerado ${ }^{1,2)}$

\begin{tabular}{|c|c|c|c|c|c|}
\hline \multirow{2}{*}{$\begin{array}{l}\text { Temperatura de } \\
\text { Armazenamento }\end{array}$} & \multicolumn{5}{|c|}{ Dias de armazenamento } \\
\hline & 0 & 3 & 6 & 9 & Médias \\
\hline \multicolumn{6}{|c|}{------------------- Newton $(\mathrm{N})$----------------- } \\
\hline $3^{\circ} \mathrm{C}$ & $6,55 \mathrm{a} A$ & $6,48 \mathrm{a} A$ & $6,46 \mathrm{a} A$ & $6,47 \mathrm{a} \mathrm{A}$ & 6,49 a \\
\hline $6^{\circ} \mathrm{C}$ & $6,55 \mathrm{a} A$ & $6,38 \mathrm{ab} \mathrm{B}$ & $6,34 \mathrm{a} \mathrm{B}$ & $6,45 \mathrm{a}$ B & $6,43 \mathrm{ab}$ \\
\hline $9^{\circ} \mathrm{C}$ & $6,55 \mathrm{a} A$ & $6,32 \mathrm{~b} \mathrm{~B}$ & 6,33a B & $6,35 \mathrm{a}$ B & $6,39 \mathrm{~b}$ \\
\hline Médias & $6,55 \mathrm{~A}$ & $6,39 \mathrm{~B}$ & $6,38 \mathrm{~B}$ & $6,42 \mathrm{~B}$ & \\
\hline
\end{tabular}

Tabela 5. Acidez total titulável de melão rendilhado minimamente processado durante o armazenamento refrigerado 1,2 )

\begin{tabular}{cccccc}
\hline $\begin{array}{c}\text { Temperatura de } \\
\text { Armazenamento }\end{array}$ & 0 & 3 & 6 & 9 & Médias \\
\hline & $0,09 \mathrm{a} \mathrm{B}$ & $0,08 \mathrm{a} \mathrm{B}$ & $0,08 \mathrm{~b} \mathrm{~B}$ & $0,09 \mathrm{~b} \mathrm{~B}$ & $0,09 \mathrm{~b}$ \\
$3^{\circ} \mathrm{C}$ & $0,09 \mathrm{a} \mathrm{B}$ & $0,09 \mathrm{a} \mathrm{B}$ & $0,09 \mathrm{ab} \mathrm{B}$ & $0,13 \mathrm{a} \mathrm{A}$ & $0,10 \mathrm{a}$ \\
$6^{\circ} \mathrm{C}$ & $0,09 \mathrm{a} \mathrm{B}$ & $0,09 \mathrm{a} \mathrm{B}$ & $0,10 \mathrm{a} \mathrm{B}$ & $0,14 \mathrm{a} \mathrm{A}$ & $0,11 \mathrm{a}$ \\
$9^{\circ} \mathrm{C}$ & $0,09 \mathrm{~B}$ & $0,085 \mathrm{~B}$ & $0,09 \mathrm{~B}$ & $0,12 \mathrm{~A}$ & \\
Médias & & & & & \\
\hline
\end{tabular}

CV (\%): 15,68

1) Médias seguidas de mesma letra minúscula na coluna e maiúscula na linha não diferem entre si, pelo teste de Tukey ao nível de 5\% de probabilidade.

${ }^{2)}$ Os valores se referem à média de acidez total titulável obtida entre os dois tipos de corte.

Observa-se na Tabela 5, que ao final do período de armazenamento, os melões mantidos a $3^{\circ} \mathrm{C}$ apresentaram notas significativamente maiores de aparência, em relação aos melões mantidos nas demais temperaturas. Verifica-se também que não houve alteração significativa desta variável, para os melões armazenados a $3^{\circ} \mathrm{C}$ durante os 9 dias de armazenamento. O'Connor-Shaw et al. (1994), também não observaram 
mudanças significativas na aparência de melões honeydew minimamente processados armazenados a $4^{\circ} \mathrm{C}$ por 14 dias.

Os melões mantidos a $6^{\circ} \mathrm{C}$ apresentaram aspecto translúcido e notas de aparência abaixo do limite de aceitabilidade (menor que 3), ao final do armazenamento. Os melões armazenados a $9^{\circ} \mathrm{C}$ apresentaram-se impróprios para o consumo já aos 6 dias de armazenamento (nota de aparência inferior a 3), devido ao aspecto de translúcido e aos 9 dias apresentou desenvolvimento de bolores em forma de colônias brancas.

Tabela 6. Aparência de melão rendilhado minimamente processado durante o armazenamento refrigerado $1,2,3)$

\begin{tabular}{cccccc}
\hline $\begin{array}{c}\text { Temperaturas de } \\
\text { Armazenamento }\end{array}$ & 0 & 3 & 6 & 9 & Médias \\
\hline $3^{\circ} \mathrm{C}$ & $5,0 \mathrm{a} \mathrm{A}$ & $3,8 \mathrm{a} \mathrm{A}$ & $4,2 \mathrm{a} \mathrm{A}$ & $3,9 \mathrm{a} \mathrm{A}$ & $4,23 \mathrm{a}$ \\
$6^{\circ} \mathrm{C}$ & $5,0 \mathrm{a} \mathrm{A}$ & $4,0 \mathrm{a} \mathrm{A}$ & $3,8 \mathrm{ab} \mathrm{A}$ & $2,4 \mathrm{~b} \mathrm{~B}$ & $3,80 \mathrm{a}$ \\
$9^{\circ} \mathrm{C}$ & $5,0 \mathrm{a} \mathrm{A}$ & $3,4 \mathrm{a} \mathrm{B}$ & $2,6 \mathrm{~b} \mathrm{~B}$ & $1,0 \mathrm{c} \mathrm{C}$ & $3,00 \mathrm{~b}$ \\
Médias & $5,00 \mathrm{~A}$ & $3,73 \mathrm{~B}$ & $3,53 \mathrm{~B}$ & $2,43 \mathrm{C}$ & \\
\hline
\end{tabular}

CV (\%): 32,57

1) Médias seguidas de mesma letra minúscula na coluna e maiúscula na linha não diferem entre si, pelo teste de Tukey ao nível de $5 \%$ de probabilidade.

${ }^{2)}$ Os valores se referem à média de aparência obtida entre os dois tipos de corte.

${ }^{3)}$ Notas: 5=ótimo; 4=bom; 3=regular; 2=ruim; 1=péssimo

$\mathrm{O}$ aroma foi considerado bom a regular até o $6^{\circ}$ dia em todos os tratamentos. No $9^{\circ}$ dia verificourse um decréscimo significativo na nota atribuída ao aroma dos melões mantidos a $9^{\circ} \mathrm{C}$, posicionando-o abaixo do limite de aceitabilidade. 
Tabela 7. Aroma de melão rendilhado minimamente processado durante o armazenamento refrigerado $1,2,3)$

\begin{tabular}{cccccc}
\hline $\begin{array}{c}\text { Temperaturas de } \\
\text { Armazenamento }\end{array}$ & 0 & 3 & 6 & 9 & Médias \\
\hline $3^{\circ} \mathrm{C}$ & $5,0 \mathrm{a} \mathrm{A}$ & $4,0 \mathrm{a} \mathrm{AB}$ & $4,0 \mathrm{a} \mathrm{AB}$ & $3,5 \mathrm{a} \mathrm{B}$ & $4,13 \mathrm{a}$ \\
$6^{\circ} \mathrm{C}$ & $5,0 \mathrm{a} \mathrm{A}$ & $3,9 \mathrm{a} \mathrm{AB}$ & $3,5 \mathrm{a} \mathrm{B}$ & $3,3 \mathrm{a} \mathrm{B}$ & $3,93 \mathrm{ab}$ \\
$9^{\circ} \mathrm{C}$ & $5,0 \mathrm{a} \mathrm{A}$ & $3,8 \mathrm{a} \mathrm{AB}$ & $3,0 \mathrm{a} \mathrm{B}$ & $1,8 \mathrm{~b} \mathrm{C}$ & $3,40 \mathrm{~b}$ \\
Médias & $5,00 \mathrm{~A}$ & $3,90 \mathrm{~B}$ & $3,50 \mathrm{BC}$ & $2,87 \mathrm{C}$ & \\
\hline
\end{tabular}

CV (\%): 27,95

${ }^{1)}$ Médias seguidas de mesma letra minúscula na coluna e maiúscula na linha não diferem entre si, pelo teste de Tukey ao nível de 5\% de probabilidade.

${ }^{2)}$ Os valores se referem à média de aroma obtida entre os dois tipos de corte.

${ }^{3)}$ Notas: 5=ótimo; 4=bom; 3=regular; 2=ruim; 1=péssimo

Em todos os tratamentos houve declínio das notas atribuídas ao sabor durante o armazenamento, sendo que no $6^{\circ}$ dia os melões mantidos a $3^{\circ} \mathrm{C}$ e $6^{\circ} \mathrm{C}$ apresentaram sabor aceitável, enquanto aqueles armazenados a $9^{\circ} \mathrm{C}$ apresentavam sabor ruim. No $9^{\circ}$ dia não efetuou-se avaliação do sabor, devido a presença de bolores nos melões armazenados a $9^{\circ} \mathrm{C}$.

Tabela 8. Sabor de melão rendilhado minimamente processado durante o armazenamento refrigerado $1,2,3)$

\begin{tabular}{ccccc}
\hline $\begin{array}{c}\text { Temperatura de } \\
\text { Armazenamento }\end{array}$ & 0 & 3 & 6 & Médias \\
\hline $3^{\circ} \mathrm{C}$ & $5,0 \mathrm{a} \mathrm{A}$ & $3,9 \mathrm{a} \mathrm{AB}$ & $3,2 \mathrm{a} \mathrm{B}$ & $4,03 \mathrm{a}$ \\
$6^{\circ} \mathrm{C}$ & $5,0 \mathrm{a} \mathrm{A}$ & $3,1 \mathrm{a} \mathrm{B}$ & $3,0 \mathrm{a} \mathrm{B}$ & $3,70 \mathrm{a}$ \\
$9^{\circ} \mathrm{C}$ & $5,0 \mathrm{a} \mathrm{A}$ & $3,7 \mathrm{a} \mathrm{B}$ & $2,2 \mathrm{a} \mathrm{C}$ & $3,63 \mathrm{a}$ \\
Médias & $5,00 \mathrm{~A}$ & $3,57 \mathrm{~B}$ & $2,80 \mathrm{C}$ & \\
\hline
\end{tabular}

CV (\%): 30,51

1) Médias seguidas de mesma letra minúscula na coluna e maiúscula na linha não diferem entre si, pelo teste de Tukey ao nível de 5\% de probabilidade.

${ }^{2)}$ Os valores se referem à média de sabor obtida entre os dois tipos de corte.

${ }^{3)}$ Notas: 5=ótimo; 4=bom; 3=regular; 2=ruim; 1=péssimo 
Pelo presente trabalho, verificoutse que ocorreu um escurecimento da região placentária dos melões durante o armazenamento em todas as temperaturas. Os teores de sólidos solúveis totais variaram com o tipo de corte, sendo que os melões fatiados apresentaram consumo significativamente menor em relação aos melões em cubos. No entanto, essa diferença não alterou as características sensoriais do produto.

Os melões armazenados a $9^{\circ} \mathrm{C}$ apresentaram decréscimo nos valores de $\mathrm{pH}$ e acréscimo na acidez total titulável, indicado processo de fermentação.

Os melões minimamente processados armazenados a $3^{\circ} \mathrm{C}$ apresentaram melhor firmeza da polpa e melhores características sensoriais ao final do armazenamento.

\subsection{Conclusões}

Pelos resultados obtidos, conclui-se que:

$>$ A melhor temperatura para armazenamento do melão rendilhado minimamente processado é $3^{\circ} \mathrm{C}$;

$>$ Os tipos de cortes (fatia ou cubo) não influenciam a qualidade do melão rendilhado minimamente processado.

$>\mathrm{O}$ melão rendilhado minimamente processado mantém boa qualidade por até 6 dias à $3^{\circ} \mathrm{C}$ 


\section{AVALIAÇÃO DE ATMOSFERA MODIFICADA PASSIVA NA QUALIDADE DE MELÃO MINIMAMENTE PROCESSADO RESUMO}

Melões rendilhados cv. Bônus II foram minimamente processados na forma de cubos, acondicionados em diversos materiais de embalagem e armazenados a $3^{\circ} \mathrm{C}$. Os materiais de embalagens utilizados foram: AFG: filme poliolefínico com antifog da DuPont $15 \mu \mathrm{m}$, HP: filme poliolefínico da Dupont $15 \mu \mathrm{m}$, PD-900: filme poliolefínico da Cryovac $58 \mu \mathrm{m}$, PEBD: filme de polietileno de baixa densidade $87 \mu \mathrm{m}$, PP: filme de polipropileno 52 $\mu \mathrm{m}$, BB-200: filme multicamada da Cryovac $65 \mu \mathrm{m}$, PET: embalagem de polietileno tereftalato rígida. Foram determinadas as taxas de permeabilidade ao $\mathrm{O}_{2} \mathrm{e}$ ao $\mathrm{CO}_{2}$ em cada uma das embalagens. As composições gasosas do espaço livre das embalagens foram determinadas diariamente durante 8 dias e no $9^{\circ}$ dia as características físico-químicas e sensoriais foram avaliadas. A taxa respiratória foi determinada nos melões inteiros e nos melões minimamente processados. Os filmes utilizados não promoveram modificação efetiva da atmosfera, mas a embalagem rígida de PET proporcionou, a partir do $6^{\circ}$ dia, uma atmosfera de equilíbrio com $12 \% \mathrm{O}_{2}$ e $7 \% \mathrm{CO}_{2}$. As características físico-químicas dos melões foram mantidas em todos os tratamentos, enquanto as características sensoriais foram mantidas apenas nos melões acondicionados na embalagem rígida de PET. A modificação passiva da atmosfera para melão minimamente processado armazenado a $3^{\circ} \mathrm{C}$, não foi verificada com as embalagens estudadas, provavelmente devido à baixa taxa respiratória observada nesta temperatura, associada a alta relação área de permeação da embalagem e massa de melão.

Palavras-chave: Cucumis melo L., processamento mínimo, armazenamento refrigerado, embalagem plástica 


\section{EVALUATION OF PASSIVE MODIFIED ATMOSPHERE IN THE QUALITY OF MINIMALLY PROCESSED MELON}

\section{SUMMARY}

Net melons cv. Bonus II were minimally processed as cubes, wrapped in different packaging materials and stored at $3^{\circ} \mathrm{C}$ for 9 days. The packaging materials used were: AFG: DuPont polyolephinic antifog film $15 \mu \mathrm{m}$; HP: DuPont polyolephinic film $15 \mu \mathrm{m}$, PD-900: Cryovac polyolephinic film $58 \mu \mathrm{m}$, PEBD: low density polyethylene film $87 \mu \mathrm{m}$; PP:polypropylene film $52 \mu \mathrm{m}$; BB-200: Cryovac polyolephinic film $65 \mu \mathrm{m}$; PET: rigid polyethylene terephtalat tray. The gas permeability of each film was determined. The gases composition inside the packaging was evaluated every day during 8 days and the physicatchemical and sensorial characteristics were evaluated at the $9^{\text {th }}$ day. The melon respiration rate was determined before and after the processing. The packaging used did not promote effective atmosphere modification, except for the PET packaging, which gave from the 6th day, atmosphere balance with $12 \% \mathrm{O}_{2}$ and $7 \% \mathrm{CO}_{2}$. Melons physical-chemical characteristics were maintained in all treatments, while the sensorial characteristics were just maintained for the wrapped melons in the PET packaging. Passive atmosphere modification for minimally processed melon stored at $3^{\circ} \mathrm{C}$, was not shown efficient, probably due to the low respiration rate observed under this temperature associated high relationship permeation area of the packing: melon mass.

Key-words : Cucumis melo L., fresh-cut, cold storage, plastic package

\subsection{Introdução}

Frutas e hortaliças minimamente processadas mantém seus tecidos vivos e não exibem a mesma resposta fisiológica que um tecido inteiro (Wiley, 1994). Os danos 
físicos causados aos tecidos pelas operações de processamento resultam na perda da integridade da membrana, destruindo a compartimentação de enzimas e substratos (Burns, 1995).

Atmosferas com 2 a $8 \%$ de $\mathrm{O}_{2}$ e 5 a $15 \%$ de $\mathrm{CO}_{2}$ têm potencial para aumentar a vida útil destes produtos e viabilizar a comercialização de frutas e hortaliças minimamente processadas. Porém, para cada vegetal existe uma atmosfera específica que maximiza sua durabilidade (Cantwell, 1992).

Vários materiais de embalagens têm sido utilizados para acondicionar frutas e hortaliças inteiras e minimamente processadas. Dentre eles incluem polietileno de baixa densidade, polietileno de alta densidade, polipropileno, poliestireno e cloreto de polivinila. Conhecendo as características respiratórias e condições gasosas ótimas do produto, pode-se selecionar um filme plástico com uma permeabilidade que permita entrada de $\mathrm{O}_{2}$ na embalagem, para compensar o consumo, e, também a saída de $\mathrm{CO}_{2}$ para compensar a produção pelo vegetal ( Zagory \& Kader, 1988).

Embora as embalagens sob atmosfera modificada de frutas e hortaliças minimamente processadas possam aumentar a vida útil destes produtos, elas não conseguem superar os efeitos negativos causados pelo aumento da temperatura. Portanto, a utilização de temperaturas baixas torna-se esssencial.

Portela et al (1997) relataram que melões Cantaloupe minimamente processados mantidos em alta concentração de $\mathrm{CO}_{2}(15 \%)$ mantiveram a qualidade visual acima do limite de aceitabilidade por 9 dias à $10^{\circ} \mathrm{C}$ e 15 dias a $5^{\circ} \mathrm{C}$.

$\mathrm{O}$ objetivo deste trabalho foi verificar a influência de materiais de embalagem na preservação da qualidade de melões minimamente processados, armazenados a $3^{\circ} \mathrm{C}$.

\subsection{Material e Métodos}

Melões provenientes do Rio Grande do Norte foram obtidos na Ceasa-Campinas e levados ao Laboratório de Pós-Colheita do Departamento de Produção Vegetal da Esalq/USP, onde foram lavados com detergente a fim de retirar as sujidades mais grosseiras e imersos em solução de hipoclorito de sódio a 100ppm, por 10 minutos, para 
evitar contaminação durante o corte. Terminada esta etapa, os melões permaneceram por 12 horas em câmara fria a $10^{\circ} \mathrm{C}$ e a seguir foram submetidos ao processamento, o qual constou das seguintes etapas:

a) Corte: Os melões foram cortados ao meio e as sementes retiradas com auxílio de uma colher. Cada metade foi cortada em 4 fatias longitudinais e em seguida as cascas foram eliminadas. As fatias foram cortadas em cubos de aproximadamente $3 \mathrm{~cm}$ de base. Este procedimento foi realizado em câmara fria a $12^{\circ} \mathrm{C}$, sob condições higiênicas.

b) Desinfecção: O fruto cortado foi imerso em solução de hipoclorito de sódio a 100 ppm por 3 segundos, com objetivo de reduzir riscos de contaminação.

c) Eliminação do excesso de água: Os pedaços de melão foram drenados por aproximadamente 1 minuto em escorredor doméstico, devidamente higienizado.

d) Embalagem: Após retirada do excesso de água, os pedaços de melão foram distribuídos em bandejas de poliestireno rígida sem tampa com capacidade de 750 $\mathrm{ml}$, as quais foram revestidas com filmes plásticos, constituindo os seguintes tratamentos:

1) AFG: Filme poliolefínico com anti-fog da Dupont $15 \mu \mathrm{m}$;

2) HP: Filme poliolefínico da Dupont $15 \mu \mathrm{m}$;

3) PD-900: Filme poliolefínico da Cryovac $58 \mu \mathrm{m}$;

4) PEBD: Filme de polietileno de baixa densidade $87 \mu \mathrm{m}$;

5) PP: Filme de polipropileno $52 \mu \mathrm{m}$;

6) BB-200: Filme multicamada da Cryovac $65 \mu \mathrm{m}$.

Os materiais de embalagem foram utilizados na forma de sacos com tamanho 25 x $20 \mathrm{~cm}$, os quais foram selados em seladora Everest. 
Um outro tratamento foi constituído de bandejas rígida de polietileno tereftalato com capacidade de $500 \mathrm{ml}$ e tampa do mesmo material da bandeja, sem o revestimento do filme.

Em seguida todas as bandejas foram armazenadas em câmara refrigerada a $3^{\circ} \mathrm{C}$, durante 9 dias. As análises físico-químicas e sensoriais foram realizadas no início do experimento e ao final do armazenamento. A composição gasosa do espaço livre das embalagens foi monitorada diariamente. Determinou-se, ainda, a taxa de permeabilidade dos materiais de embalagem e a taxa respiratória dos melões inteiros e cortados.

O delineamento experimental foi inteiramente ao acaso com 7 tratamentos e 5 repetições. Cada repetição foi constituída por uma bandeja contendo aproximadamente $240 \mathrm{~g}$ do produto minimamente processado nas bandejas de $750 \mathrm{ml} \mathrm{e} 210 \mathrm{~g}$ do produto nas bandejas de $500 \mathrm{ml}$.

\section{- Descrição das análises}

\section{Caracterização dos materiais de embalagem:}

A taxa de permeabilidade ao $\mathrm{O}_{2}$ e ao $\mathrm{CO}_{2}$ foi determinada por método de aumento da concentração, segundo procedimento descrito por Oliveira et al (1996).

Foram utilizadas células de difusão de gás constituídas por 2 câmaras. Na câmara superior foi mantido um fluxo de gás permeante, que ao permear o corpo de prova acumulou-se na câmara inferior, fechada para atmosfera. Em intervalos prédeterminados foram retiradas alíquotas de $300 \mu \mathrm{L}$ de gás, desta câmara, para quantificação do gás permeante em cromatógrafo a gás marca Shimadzu, modelo 14A. Os resultados de cromatografia foram analisados por um integrador, com base em curva padrão feita com gás de calibração.

A área de permeação efetiva das embalagens foi determinada pelo produto das dimensões entre as linhas de selagem das embalagens. Foram medidas todas as embalagens de cada tratamento e calculadas as médias aritméticas. 
Determinação da composição gasosa do espaço livre das embalagens:

Para o monitoramento da composição gasosa foi fixado um septo de silicone em cada embalagem, através do qual foram coletadas amostras de gás do interior das mesmas. Utilizou-se um analisador de gases marca PBI-Dansensor, modelo Check Mate, o qual retira aproximadamente $2 \mathrm{ml}$ de gás por amostragem. Foram realizadas leituras diárias e os resultados expressos em $\% \mathrm{O}_{2}$ e $\% \mathrm{CO}_{2}$.

Determinação da taxa respiratória:

Melões selecionados foram sanitizados e divididos em 3 lotes de 6 frutos, os quais foram armazenados a $3^{\circ} \mathrm{C}$ por $12 \mathrm{~h}$. Decorrido este período, os melões foram colocados em tambores herméticos para determinação da taxa respiratória, a qual foi obtida retirando-se amostras de gás do interior dos tambores, através de um septo. Para tanto, utilizourse analisador de gases marca PBI-Dansensor, modelo Check Mate, o qual retira aproximadamente $2 \mathrm{ml}$ de gás por amostragem. Os resultados expressos em \% $\mathrm{CO}_{2}$ foram utilizados para o cálculo da taxa respiratória, levando-se em consideração o volume do tambor, a massa de melão e o tempo que o tambor permaneceu fechado.

A seguir, os melões foram minimamente processados em cubos, acondicionados em jarros herméticos e armazenados a $3^{\circ} \mathrm{C}$. A taxa respiratória foi medida nas primeiras 10 horas, em intervalos de 2 horas. Posteriormente, as leituras foram realizadas em intervalos de 24 horas durante 6 dias. O procedimento para determinação da taxa respiratória foi semelhante ao utilizado para melões inteiros.

Avaliação das características físico-químicas dos melões minimamente processados:

As análises físico-químicas foram realizadas no dia do processamento e após 9 dias, quanto à:

a) Escurecimento: Determinado com colorímetro Minolta, modelo CR-300, tomando-se uma leitura na região placentária. As leituras foram realizadas em 6 cubos por repetição e os resultados expressos em Luminosidade $\left(\mathrm{L}^{*}\right)$ 
b) Firmeza da polpa: Determinada com penetrômetro digital, ponteira $8 \mathrm{~mm}$, tomandose uma leitura na região placentária do cubo. As leituras foram realizadas em 6 cubos por repetição, sendo os resultados expressos em Newton (N).

c) Teores de Sólidos Solúveis Totais (SST): Leitura direta em refratômetro digital Atago modelo Palete 101, utilizando-se polpa homogeneizada em triturador doméstico, tipo 'mixer'. Os resultados foram expressos em ${ }^{\circ}$ Brix.

d) $\mathrm{pH}$ : Leitura em solução de polpa homogeneizada, com pHmetro marca Tecnal.

$\underline{\text { Avaliação das características sensoriais dos melões minimamente processados: }}$

A avaliação sensorial (aparência e aroma) foi realizada por uma equipe de 5 provadores utilizando escala de notas, onde: 5=ótimo; $4=$ bom; $3=$ regular; $2=$ ruim e 1=péssimo. A nota 3 foi considerada como limite de aceitabilidade. Os pedaços de melões foram oferecidos aos provadores depois de mantidos por 3 horas sob temperatura ambiente.

A descrição das notas encontra-se a seguir:

Aparência: 5= melão com aspecto de frescor, ausência de escurecimento, translucência e bolores; $4=$ melão com aspecto de frescor, porém com leve escurecimento na região placentária e/ou leve translucência e ausência de bolores; $3=$ melão com pouco aspecto de frescor, moderado escurecimento na região placentária e/ou moderada translucência e ausência de bolores; $2=$ melão sem aspecto de frescor, elevado escurecimento na região placentária e/ou elevado grau de translucência e ausência de bolores; $1=$ melão com elevado grau de translucência e com bolores.

Aroma: 5= melão com aroma forte (típico de net melon); 4= melão com aroma moderado; $3=$ melão com aroma fraco ou sem aroma; $2=$ melão com aroma alcoólico; $1=$ melão com aroma de produto putrefado.

Os resultados foram submetidos à análise de variância pelo teste $\mathrm{F}$ e comparados com o padrão ( resultados obtidos no dia do processamento) pelo teste bilateral de Dunnet (5\% de probabilidade de erro). 


\subsection{Resultados e Discussão}

\section{Composição gasosa do espaço livre das embalagens}

Verifica-se, pela Figura 1, que a modificação da composição gasosa do interior das embalagens revestidas por filmes plásticos foi muito pequena, ficando aquém daquela recomendada por Cantwell (1992), para preservação de frutas e hortaliças minimamente processadas.

Nas embalagens revestidas pelos filmes AFG e HP a concentração de $\mathrm{O}_{2}$ manteve-se praticamente igual à do ambiente e a de $\mathrm{CO}_{2}$ entre 1,17 e 0,74\%. Estes materiais de embalagem apresentam alta taxa de permeabilidade ao $\mathrm{O}_{2}\left(>10.000 \mathrm{~cm}^{3} \cdot \mathrm{m}^{-}\right.$ $\left.{ }^{2} \cdot \mathrm{dia}^{-1}\right)$ e ao $\mathrm{CO}_{2}\left(>39.000 \mathrm{~cm}^{3} \cdot \mathrm{m}^{-2} \cdot \mathrm{dia}^{-1}\right)$ (Tabela 1$)$.

Em relação às embalagens constituídas pelos filmes PD-900, PEBD e PP as concentrações de $\mathrm{O}_{2}$ observadas ao final do período de armazenamento foram de 18,73; 18,94 e $17,98 \%$ e as concentrações de $\mathrm{CO}_{2}$ foram 1,$83 ; 2,40$ e 3,85\%, respectivamente. Nota-se que, embora as taxas de permeabilidade destes filmes sejam 3 a 7 vezes menores que dos filmes AFG E HP, a modificação da atmosfera não ocorreu ao nível desejado, para manter a qualidade dos melões.

De acordo com Smith et al. (1987) a magnitude das alterações das concentrações de gases do espaço livre das embalagens depende da natureza e da espessura da barreira, taxa respiratória do produto, relação entre massa do produto e área superficial da barreira, temperatura e umidade.

O filme BB-200 é considerado material de alta barreira, por apresentar taxas de permeabilidade bastante baixa, conforme pode ser observado na Tabela 1. Esperava-se que este filme promovesse modificação significativa da composição gasosa no interior da embalagem. Entretanto, a concentração de $\mathrm{O}_{2}$ estabilizourse em torno de $18,58 \%$ e a de $\mathrm{CO}_{2}$ aumentou lentamente atingindo $3,74 \%$ ao final do armazenamento. Este comportamento provavelmente seja decorrente da alta relação entre a área efetiva de permeação da embalagem e a massa de melão (Tabela 2) associada à baixa taxa 
respiratória. $\mathrm{Na}$ embalagem $\mathrm{PET}$ os níveis de $\mathrm{O}_{2}$ e $\mathrm{CO}_{2}$ atingiram valores de 6,91\% e $11,57 \%$, respectivamente, ao final do armazenamento.

Verificourse, portanto, a mais drástica modificação da atmosfera entre os tratamentos estudados, embora, a taxa de permeabilidade ao $\mathrm{O}_{2}$ deste material seja alta (Tabela 1). Provavelmente, esta diferença de comportamento, em relação aos demais tratamentos, seja devido à menor relação entre a área de permeação e a massa de melão (Tabela 2). Embora as concentrações de $\mathrm{O}_{2}$ e $\mathrm{CO}_{2}$ atingidas estejam dentro da faixa proposta por Cantwell (2000) para preservação de frutas e hortaliças minimamente processadas, a estabilização dos gases ocorreu somente após o $6^{\circ}$ dia, ou seja, no final do período de armazenamento.

A Figura 2 ilustra a taxa respiratória do melão inteiro e minimamente processado armazenado à $3^{\circ} \mathrm{C}$. Observa-se que imediatamente após o corte a taxa respiratória sofreu incremento de aproximadamente três vezes em relação aos frutos inteiros e 24 horas após o processamento, a taxa respiratória assumiu valores semelhantes àqueles verificados antes do processamento. 

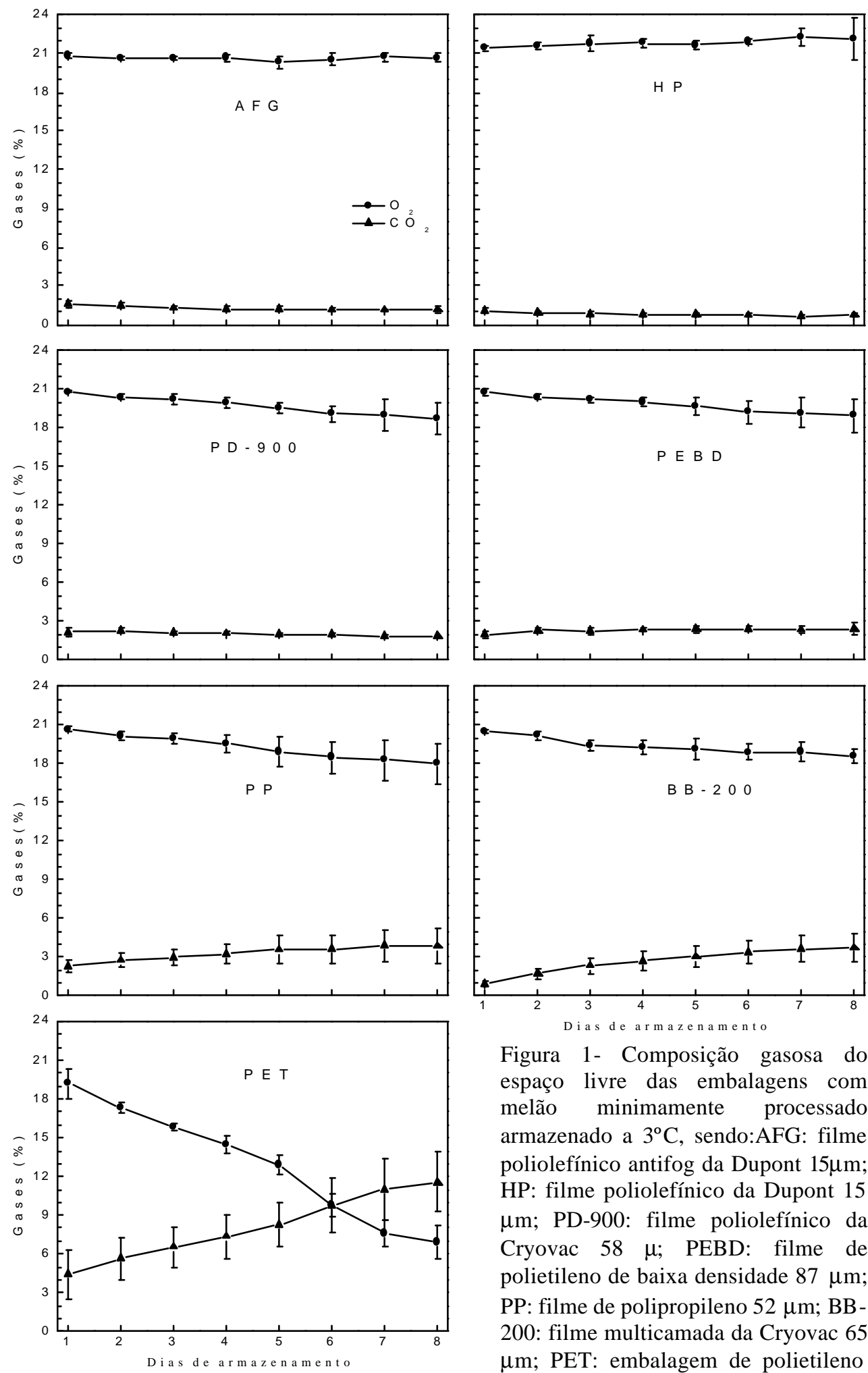

Figura 1- Composição gasosa do espaço livre das embalagens com melão minimamente processado armazenado a $3^{\circ} \mathrm{C}$, sendo:AFG: filme poliolefínico antifog da Dupont $15 \mu \mathrm{m}$; HP: filme poliolefínico da Dupont 15 $\mu \mathrm{m}$; PD-900: filme poliolefínico da Cryovac $58 \mu$; PEBD: filme de polietileno de baixa densidade $87 \mu \mathrm{m}$; PP: filme de polipropileno $52 \mu \mathrm{m}$; BB200: filme multicamada da Cryovac 65 $\mu \mathrm{m}$; PET: embalagem de polietileno rígida. 
Tabela 1. Características dos materiais de embalagem

\begin{tabular}{lccc}
\hline \multicolumn{1}{c}{ Materiais de embalagem } & $\begin{array}{c}\text { Espessura } \\
(\mu \mathrm{m})\end{array}$ & $\begin{array}{c}\mathrm{TPO}_{2} \\
\left(\mathrm{~cm}^{3} \cdot \mathrm{m}^{-2} \cdot \mathrm{dia}^{-1}\right)\end{array}$ & $\begin{array}{c}\mathrm{TPCO}_{2} \\
\left(\mathrm{~cm}^{3} \cdot \mathrm{m}^{-2} \cdot \mathrm{dia}^{-1}\right)\end{array}$ \\
\hline $\begin{array}{l}\text { AFG: Filme poliolefínico anti- } \\
\text { fog da Dupont }\end{array}$ & 15 & 12.232 & 45.526 \\
$\begin{array}{l}\text { HP: Filme poliolefínico da } \\
\text { Dupont }\end{array}$ & 15 & 10.013 & 39.828 \\
$\begin{array}{l}\text { PD-900: Filme poliolefínico da } \\
\text { Cryovac }\end{array}$ & 58 & 3.433 & 15.946 \\
$\begin{array}{l}\text { PEBD: Filme de polietileno de } \\
\text { baixa densidade }\end{array}$ & 87 & 2.024 & 5.860 \\
$\begin{array}{l}\text { PP: Filme de polipropileno } \\
\begin{array}{l}\text { BB-200: Filme multicamada } \\
\text { da Cryovac }\end{array}\end{array}$ & 52 & 1.961 & 6.821 \\
$\begin{array}{l}\text { PET: embalagem de } \\
\text { polietileno rígida }\end{array}$ & 65 & 9 & 25 \\
\hline
\end{tabular}

Tabela 2. Características das embalagens

\begin{tabular}{lccc}
\hline \multicolumn{1}{c}{ Materiais de embalagem } & $\begin{array}{c}\text { Área de permeação (A) } \\
\left(\mathrm{cm}^{2}\right)\end{array}$ & $\begin{array}{c}\text { Massa de melão(B) } \\
(\mathrm{g})\end{array}$ & $\begin{array}{c}\text { Relação A/B } \\
\left(\mathrm{cm}^{2} / \mathrm{g}\right)\end{array}$ \\
\hline $\begin{array}{l}\text { AFG: Filme poliolefínico anti } \\
\text { fog da Dupont }\end{array}$ & 640 & 240 & 2,67 \\
$\begin{array}{l}\text { HP: Filme poliolefínico da } \\
\begin{array}{l}\text { Dupont } \\
\text { PD-900: Filme poliolefínico da }\end{array}\end{array}$ & 760 & 240 & 3,17 \\
$\begin{array}{l}\text { Cryovac } \\
\text { PEBD: Filme de polietileno de } \\
\text { baixa densidade }\end{array}$ & 960 & 240 & 2,92 \\
$\begin{array}{l}\text { PP: Filme de polipropileno } \\
\text { BB-200: Filme multicamada } \\
\text { da Cryovac }\end{array}$ & 880 & 240 & 4,00 \\
$\begin{array}{l}\text { PET: embalagem de } \\
\text { polietileno rígida }\end{array}$ & 896 & 240 & 3,67 \\
\hline
\end{tabular}




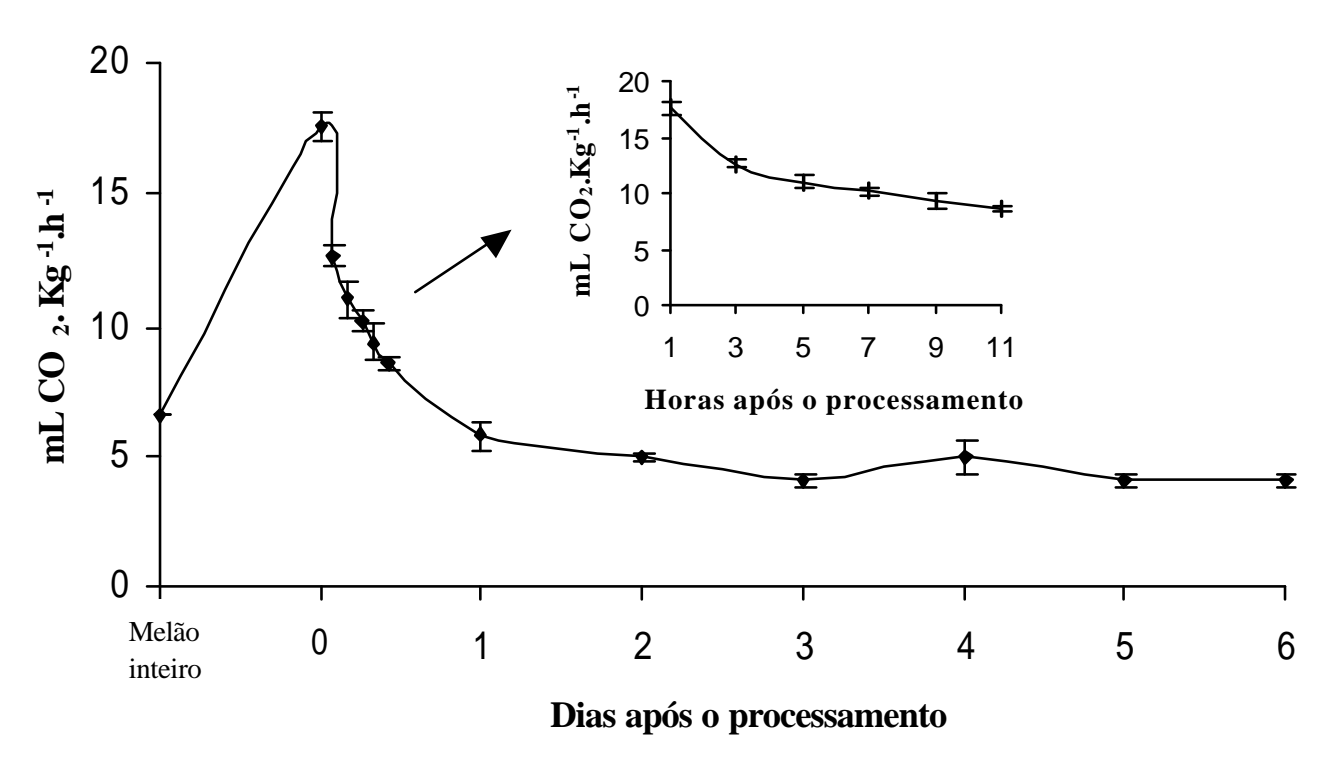

Figura 2 - Taxa respiratória de melão inteiro e minimamente processado a $3^{\circ} \mathrm{C}$

\section{Características físico-químicas dos melões minimamente processados}

Verifica-se, na Tabela 2, que as características físico-químicas foram mantidas durante o armazenamento. A manutenção da firmeza e a retenção do escurecimento ocorreram devido a baixa temperatura de armazenamento $\left(3^{\circ} \mathrm{C}\right)$, visto que não houve uma modificação efetiva da atmosfera.

Provavelmente, a baixa temperatura reduziu a atividade das enzimas responsáveis pelo escurecimento enzimático e perda de firmeza. Enzimas proteolíticas são responsáveis pela perda de firmeza das frutas e hortaliças minimamente processadas (Wiley, 1994), enquanto as enzimas peroxidase e polifenoloxidase são responsáveis pelo escurecimento do tecido vegetal (Darezzo, 2000).

A estabilidade dos teores de sólidos solúveis totais e $\mathrm{pH}$, provavelmente, também esteja associada a baixas temperaturas. Lamikanra et al. (2000) também não observaram mudanças significativas nos teores de sólidos solúveis totais e pH de melões Cantaloupe minimamente processados armazenados a $4^{\circ} \mathrm{C}$ por 14 dias. 
Tabela 3. Característica físico-química de melão rendilhado minimamente processado, acondicionado em diversos materiais de embalagem e armazenado a $3^{\circ} \mathrm{C}$ durante 9 dias.

\begin{tabular}{|c|c|c|c|c|}
\hline Embalagens & $\begin{array}{c}\text { Coloração } \\
\text { (Luminosidade) }\end{array}$ & $\begin{array}{l}\text { Firmeza } \\
\text { (Newton) }\end{array}$ & $\begin{array}{c}\text { Sólidos } \\
\text { Solúveis } \\
\text { ( }{ }^{\circ} \text { Brix) }\end{array}$ & $\mathrm{pH}$ \\
\hline PADRÃO $^{1}$ & 61,66 & 5,42 & 7,94 & 5,75 \\
\hline $\begin{array}{l}\text { AFG: filme poliolefínico } \\
\text { antifog da Dupont } 15 \mu \mathrm{m}\end{array}$ & $57,13 \mathrm{NS}$ & $3,06 \mathrm{NS}$ & 7,83 NS & $5,89 \mathrm{NS}$ \\
\hline $\begin{array}{l}\text { HP: filme poliolefínico da } \\
\text { Dupont } 15 \mu \mathrm{m}\end{array}$ & $60,35 \mathrm{NS}$ & 3,52 NS & $7,42 \mathrm{NS}$ & $5,73 \mathrm{NS}$ \\
\hline $\begin{array}{l}\text { PD-900: filme poliolefínico } \\
\text { da Cryovac } 58 \mu \mathrm{m}\end{array}$ & $54,71 \mathrm{NS}$ & $3,37 \mathrm{NS}$ & 7,80 NS & $5,83 \mathrm{NS}$ \\
\hline $\begin{array}{l}\text { PEBD: filme de polietileno } \\
\text { de baixa densidade } 87 \mu \mathrm{m}\end{array}$ & $59,47 \mathrm{NS}$ & $4,14 \mathrm{NS}$ & $7,74 \mathrm{NS}$ & $5,74 \mathrm{NS}$ \\
\hline $\begin{array}{l}\text { PP: filme de polipropileno } 52 \\
\mu \mathrm{m}\end{array}$ & $59,86 \mathrm{NS}$ & $3,70 \mathrm{NS}$ & $7,85 \mathrm{NS}$ & $5,64 \mathrm{NS}$ \\
\hline $\begin{array}{l}\text { BB-200: filme poliolefínico } \\
\text { da Cryovac } 65 \mu \mathrm{m}\end{array}$ & $56,18 \mathrm{NS}$ & $4,72 \mathrm{NS}$ & 7,24 NS & $5,90 \mathrm{NS}$ \\
\hline $\begin{array}{l}\text { PET: embalagem de } \\
\text { polietileno rígida }\end{array}$ & $63,53 \mathrm{NS}$ & $3,50 \mathrm{NS}$ & $6,90 \mathrm{NS}$ & $5,73 \mathrm{NS}$ \\
\hline $\mathrm{CV}(\%)$ & 14,54 & 41,96 & 16,59 & 4,0 \\
\hline
\end{tabular}

NS: Não diferem do padrão ao nível de 5\% de probabilidade pelo teste de Dunnet.

${ }^{1}$ Refere-se à qualidade do melão no dia do processamento.

\section{Características sensoriais de melões minimamente processados}

As características sensoriais dos melões minimamente processados, acondicionados na embalagem PET, não sofreram alteração durante o armazenamento. A boa aparência do melão deste tratamento foi devida a ausência de escurecimento e translucência, embora em nenhum tratamento observoutse escurecimento. Provavelmente, a manutenção da coloração ocorreu devido à baixa temperatura de armazenamento, enquanto a ausência de translucência pode ser explicada pelo acúmulo de $\mathrm{CO}_{2}$ nessa embalagem.

Portela \& Cantwell (1998) estudaram mudanças na qualidade de melões honeydew minimamente processado armazenado no ambiente e em atmosfera controlada 
e verificaram que altas concentrações de $\mathrm{CO}_{2}$ evitaram o aparecimento de translucência. Os mesmos autores também verificaram o efeito do $\mathrm{CO}_{2}$ na redução da perda de aroma. No presente trabalho, os resultados de aroma estão de acordo com os observados por estes autores, já que os melões sob a mais alta concentração de $\mathrm{CO}_{2}$ mantiveram o aroma.

Tabela 4. Características sensoriais de melão rendilhado minimamente processado acondicionado em diversos materiais de embalagem e armazenado a $3^{\circ} \mathrm{C}$ durante 9 dias à $3^{\circ} \mathrm{C}$. (Notas: 5=ótimo; 4=bom; 3= regular; 2=ruim; 1= péssimo).

\begin{tabular}{lcc}
\hline \multicolumn{1}{c}{ Materiais de embalagem } & Aparência & Aroma \\
\hline PADRÃO $^{1}$ & 5,0 & 5,0 \\
$\begin{array}{l}\text { AFG: Filme poliolefínico anti } \\
\text { fog da Dupont } 15 \mu \mathrm{m}\end{array}$ & $3,0 *$ & $3,2 *$ \\
HP: Filme poliolefínico da & $3,4 *$ & $3,4 *$ \\
$\begin{array}{l}\text { Dupont } 15 \mu \mathrm{m} \\
\text { PD-900: Filme poliolefínico da }\end{array}$ & $3,0 *$ & $3,4 *$ \\
$\begin{array}{l}\text { Cryovac } 58 \mu \mathrm{m} \\
\text { PE: Filme de polietileno de }\end{array}$ & $3,0 *$ & $3,0 *$ \\
baixa densidade $87 \mu \mathrm{m}$ & & $3,4 *$ \\
PP: Filme de polipropileno 52 & $3,0 *$ & $3,25 *$ \\
$\begin{array}{l}\mu \mathrm{m} \\
\text { BB-200: Filme poliolefínico } \\
\text { da Cryovac } 65 \mu \mathrm{m}\end{array}$ & $3,0 *$ & $4,6 \mathrm{NS}$ \\
PET: embalagem de \\
$\begin{array}{l}\text { polietileno rígida } \\
\text { CV(\%) }\end{array}$
\end{tabular}

* Diferem do padrão ao nível de 5\% de probabilidade pelo teste de Dunnet. NS: Não diferem do padrão ao nível de $5 \%$ de probabilidade pelo teste de Dunnet.

${ }^{1}$ Refere-se à qualidade do melão no dia do processamento. 


\subsection{Conclusões}

- As características físico-químicas dos melões minimamente processados armazenados a $3^{\circ}$ durante 9 dias foram mantidas, mesmo sob atmosfera com composição gasosa semelhante à do ar.

- As características sensoriais dos melões minimamente processados armazenados a $3^{\circ} \mathrm{C}$ durante 9 dias foram mantidas apenas no tratamento que promoveu maior modificação da atmosfera $\left(7 \% \mathrm{CO}_{2}\right.$ e $\left.12 \% \mathrm{O}_{2}\right)$.

- Melões minimamente processados, acondicionados em embalagens com relação [área de permeação $\left(\mathrm{cm}^{2}\right) /$ massa de melão $(\mathrm{g})$ ] $>2$ e $\operatorname{armazenados}$ a $3^{\circ} \mathrm{C}$ promovem pouca modificação da atmosfera. 


\section{AVALIAÇÃO DE ATMOSFERA MODIFICADA ATIVA NA QUALIDADE DE MELÃO MINIMAMENTE PROCESSADO}

\section{RESUMO}

Melões rendilhados cv. Bônus II foram minimamente processados na forma de cubos, acondicionados em diversos materiais de embalagem com injeção da mistura gasosa $\left(5 \% \mathrm{O}_{2}+20 \% \mathrm{CO}_{2}+75 \% \mathrm{~N}_{2}\right)$ e armazenados a $3^{\circ} \mathrm{C}$ durante 12 dias. Os materiais de embalagem foram:BB-200: filme multicamada da Cryovac $65 \mu \mathrm{m}$; PBC:filme poliolefínico Probag Conservax 64 $\mu \mathrm{m}$; PP: filme de polipropileno $52 \mu \mathrm{m}$. Como controle, utilizourse bandeja de poliestireno com tampa perfurada. Realizou-se monitoramento da composição gasosa, análises microbiológicas, sensoriais e físicoquímicas a cada 3 dias. Foram determinadas as taxas de permeabilidade ao $\mathrm{O}_{2}$ e $\mathrm{CO}_{2}$ de cada filme. A embalagem BB-200 promoveu acúmulo de $\mathrm{CO}_{2}$ até níveis de $24 \%$ e redução de $\mathrm{O}_{2}$ até níveis de $0,4 \%$. Na embalagem $\mathrm{PBC}$ a concentração de $\mathrm{O}_{2}$ estabilizout se ao redor de $8 \%$ e a de $\mathrm{CO}_{2}$ ao redor de $4 \%$, enquanto na embalagem de PP os níveis de gases estabilizaram-se ao redor de $13 \% \quad \mathrm{O}_{2}$ e $6 \% \quad \mathrm{CO}_{2}$. De maneira geral, as características físico químicas e sensoriais foram pouco influenciadas pelos tratamentos. A alteração da composição gasosa foi eficiente no controle de microrganismos. A partir do $9^{\circ}$ dia de armazenamento, os melões controle apresentaram níveis de bactérias mesófilas acima de $10^{5} \mathrm{NMP} / \mathrm{g}$, com riscos de apresentarem microrganismos patogênicos.

Palavras-chave: Cucumis melo L., processamento mínimo, armazenamento refrigerado, mistura gasosa, microbiologia 


\section{EVALUATION OF ACTIVE MODIFIED ATMOSPHERE IN THE QUALITY OF MINIMALLY PROCESSED MELON}

\section{SUMMARY}

Net melons cv. Bonus II were minimally processed as cubes, wrapped in several packaging materials with injection of the gaseous mixture $\left(5 \% \mathrm{O}_{2}+20 \% \mathrm{CO}_{2}+75 \%\right.$ $\mathrm{N}_{2}$ ) and stored at $3^{\circ} \mathrm{C}$ for 12 days. The packaging materials were: BB-200: Cryovac

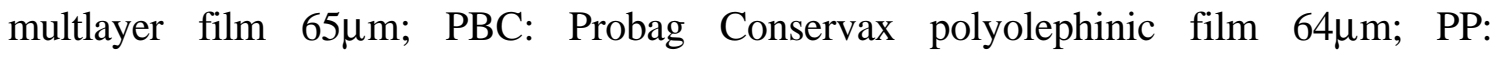
polypropylene film $52 \mu \mathrm{m}$. Polystyrene trays were used as control with perforated cover. Gaseous composition inside of the packaging, microbiological, sensorial and physicat chemical characteristics were determined each 3 days. The gas permeability was determined for each film. BB-200 packaging promoted $\mathrm{CO}_{2}$ accumulation until $24 \%$ and $\mathrm{O}_{2}$ reduction until $0,4 \%$. Inside $\mathrm{PBC}$ packaging the $\mathrm{O}_{2}$ concentration stabilized at $8 \%$ and $\mathrm{CO}_{2}$ about $4 \%$, while inside PP packaging the gaseous concentration stabilized near $13 \%$ for $\mathrm{O}_{2}$ and $6 \%$ for $\mathrm{CO}_{2}$. In a general sense, physicalchemical and sensorial characteristics were not influenced by the treatments. The modified atmosphere packaging was efficient for the microorganism control. The melon without modified

atmosphere packaging showed after $9^{\text {th }}$ storage day levels over $10^{5} \mathrm{NMP} / \mathrm{g}$, of mesophilics bacteria, wich pathogenic microorganisms risks.

Keywords: Cucumis melo L., fresh-cut, cold storage, gaseous mixture, microbiology

\subsection{Introdução}

O processamento mínimo é definido como qualquer alteração física, causada em frutas ou hortaliças, que mantém o estado fresco desses produtos. Inclui operações de seleção, lavagem, corte, sanitização, centrifugação, embalagem, armazenamento e comercialização (IFPA, 1999; Moretti, 1999).

A mudança nos padrões de consumo de alimentos tem levado ao maior consumo de frutas e hortaliças em detrimento dos produtos industrializados. Ao mesmo tempo, os 
consumidores desejam produtos com qualidade e praticidade. Nesse sentido, a demanda por frutas e hortaliças minimamente processadas tem evoluído rapidamente (Shewfelt, 1987; Burns, 1995).

Um dos maiores problemas dos produtos minimamente processados é sua rápida deterioração. As injúrias provocadas no tecido, por ocasião do corte, elevam a taxa respiratória e a produção de etileno. O etileno contribui para a biossíntese de enzimas envolvidas em mudanças fisiológicas e bioquímicas. (Brecht, 1995). De acordo com Mathooko (1996), níveis elevados de $\mathrm{CO}_{2}$ inibem a síntese de etileno, o que indica que este tratamento pode ser utilizado para conservação de produtos hortícolas minimamente processados.

A modificação da atmosfera em uma embalagem plástica pode ser estabelecida de forma passiva ou ativa. A atmosfera modificada passiva se estabelece pela própria respiração do produto, enquanto em atmosfera modificada ativa é feito uma injeção de gases no momento em que o produto é embalado (Kader, 1986).

Em produtos onde o consumo de $\mathrm{O}_{2}$ é baixo e a atmosfera modificada se estabelece lentamente, as reações bioquímicas podem causar deterioração no produto antes que ocorra o equilíbrio dos gases (Wiley,1994).

Sendo assim, a principal vantagem da atmosfera modificada ativa está na rapidez com que a atmosfera desejada é estabelecida. O objetivo deste trabalho foi avaliar os efeitos de materiais de embalagem, associados a atmosfera modificada ativa na preservação da qualidade de melões minimamente processados.

\subsection{Material e Métodos}

\section{- Obtenção dos melões}

Utilizaram-se melões rendilhados cv. Bônus II provenientes do Rio Grande do Norte. Os frutos foram adquiridos na Ceasa-Campinas e levados ao Laboratório de PósColheita do Departamento de Produção Vegetal da Esalq/USP, onde foram lavados com detergente a fim de retirar as sujidades mais grosseiras, sendo em seguida imersos em 
solução de hipoclorito de sódio a 100 ppm por 10 minutos para evitar contaminação durante o processamento. Terminada esta etapa, os melões permaneceram por $12 \mathrm{~h}$ em câmara fria a $10^{\circ} \mathrm{C}$.

\section{- Processamento}

Os melões refrigerados foram processados em câmara fria a $12^{\circ} \mathrm{C}$ sobre mesa de inox, devidamente higienizada. Os operadores utilizaram botas, aventais, luvas, máscaras e toucas, como parte das condições mínimas de assepsia.

As etapas do processamento constaram de:

a) Corte: Os melões foram cortados ao meio e as sementes retiradas com auxílio de uma colher. Cada metade foi cortada em 4 fatias longitudinais que tiveram as cascas eliminadas. As fatias foram porcionadas em cubos de aproximadamente $3 \mathrm{~cm}$ de base.

b) Desinfecção: Os pedaços foram imersos em solução de hipoclorito de sódio a 100 ppm por 3 segundos, com objetivo de reduzir riscos de contaminação.

c) Eliminação do excesso de água: Os pedaços de melões foram drenados por aproximadamente 1 minuto em escorredor doméstico, devidamente higienizado.

d) Embalagem: Após a retirada do excesso de água, os pedaços de melão foram colocados em bandejas de poliestireno rígida sem tampa, com capacidade de $750 \mathrm{ml}$, as quais foram colocadas em sacos plásticos constituídos de diferentes filmes. A selagem foi efetuada ita em seladora à vácuo Selovac. Efetuou-se evacuação do ar do interior da embalagem e injeção da mistura gasosa. Como controle utilizou-se bandeja de poliestireno rígida com tampa perfurada para evitar a modificação da atmosfera em seu interior. Os materiais de embalagem (filmes plásticos) utilizados foram:

BB-200: Filme multicamada da Cryovac $65 \mu \mathrm{m}$;

PBC: Filme poliolefínico Probag Conservax $64 \mu \mathrm{m}$; 
PP: Filme de polipropileno $52 \mu \mathrm{m}$;

Ao final do processo de embalagem, o produto foi armazenado em câmara fria a $3^{\circ} \mathrm{C}$. A cada 3 dias foram realizadas análises físico-químicas, sensoriais e microbiológicas e monitoramento da composição gasosa do espaço livre das embalagens.

O delineamento experimental foi inteiramente casualizado com 4 tratamentos e 5 repetições, sendo cada repetição representada por uma bandeja contendo aproximadamente $240 \mathrm{~g}$ do produto minimamente processado. Os resultados foram submetidos à análise de variância pelo teste $\mathrm{F}$ e comparação de médias pelo teste de Tukey $(5 \%)$.

\section{- Descrição das análises}

\section{Caracterização dos materiais de embalagem:}

A taxa de permeabilidade ao $\mathrm{O}_{2}$ e ao $\mathrm{CO}_{2}$ foi determinada por método de aumento da concentração, segundo procedimento descrito por Oliveira et al (1996).

Foram utilizadas células de difusão de gás constituídas por 2 câmaras. Na câmara superior foi mantido um fluxo de gás permeante, que ao permear o corpo de prova acumulou-se na câmara inferior, fechada para atmosfera. Em intervalos prédeterminados foram retiradas alíquotas de $300 \mu \mathrm{L}$ de gás, desta câmara, para quantificação do gás permeante em cromatógrafo a gás marca Shimadzu, modelo 14A. Os resultados de cromatografia foram analisados por um integrador, com base em curva padrão feita com gás de calibração.

A área de permeação efetiva das embalagens foi determinada pelo produto das dimensões entre as linhas de selagem das embalagens. Foram medidas todas as embalagens de cada tratamento e calculadas as médias aritméticas. 
Monitoramento da composição gasosa:

Para o monitoramento da composição gasosa foi fixado em cada embalagem um septo de silicone através do qual foram coletadas amostras de gás do interior das embalagens utilizando-se um analisador de gases marca PBI-Dansensor, modelo Check Mate, o qual retira aproximadamente $2 \mathrm{ml}$ de gás por amostra. As leituras foram realizadas a cada 3 dias e os resultados foram expressos em $\% \mathrm{O}_{2} \mathrm{e} \% \mathrm{CO}_{2}$.

\section{Análises microbiológicas:}

As análises microbiológicas foram realizadas pela metodologia Simplate ${ }^{\mathrm{TM}}$. O princípio deste método baseia-se na tecnologia do substrato enzimático, correlacionando a atividade enzimática com a presença de microrganismos viáveis no alimento. $\mathrm{O}$ kit, fabricado pela Idexx Laboratories Inc consta de meio de cultura desidratado e placas descartáveis com 84 cavidades.

\section{a) Contagem total de bactérias mesófilas}

Foram analisadas 3 amostras por tratamento, sendo que cada amostra continha $20 \mathrm{~g}$ do produto. As amostras foram acondicionadas em sacos plásticos esterelizados próprios para alimentos e levadas para câmara de fluxo laminar, onde foram realizadas as análises.

\section{Procedimento de análise}

Inicialmente o meio de cultura para contagem total de mesófilos foi hidratado e homogeneizado em $100 \mathrm{ml}$ de água destilada esterilizada. As amostras foram maceradas manualmente no interior dos sacos plásticos e diluídas em $180 \mathrm{ml}$ de água peptonada esterilizada $(0,1 \%)$, constituindo a diluição $10^{-1}$. A partir da diluição $10^{-1}$, obteve-se a diluição $10^{-2}$, pipetando-se $10 \mathrm{ml}$ da solução $10^{-1}$ em $90 \mathrm{ml}$ de água peptonada esterilizada $(0,1 \%)$ e a partir desta, obteve-se a diluição $10^{-3}$. 
Foram preparadas placas com as diluições $10^{-2}$ e $10^{-3}$ das amostras de melão. Para o preparo das placas adicionou-se $1 \mathrm{ml}$ de determinada diluição $+9 \mathrm{ml}$ de meio hidratado no centro da placa, a qual foi em seguida agitada com movimento circular, de forma que todas as cavidades fossem preenchidas. Drenou-se o excesso de líquido e a seguir as placas foram invertidas e incubadas a $35^{\circ} \mathrm{C}$ por 24 horas.

Decorrido o tempo de incubação, fez se a contagem das cavidades positivas sob lâmpada ultravioleta $365 \mathrm{~nm}$. As cavidades positivas apresentam um colorido azul fluorescente sob luz ultravioleta, devido à hidrólise do substrato por enzimas bacterianas, promovendo a formação de um composto azul fluorescente, o 4metilumbeliferona (4-MU)

Após obtenção do número de cavidades positivas, consultou-se a tabela fornecida pelo fabricante e determinourse o NMP ( número mais provável) de bactérias mesófilas / g de produto, multiplicando-se o valor encontrado na Tabela, correspondente ao número de cavidades positivas, pelo inverso da diluição.

\section{b) NMP de coliformes totais e Escherichia coli}

Realizou-se o mesmo procedimento das análises para contagem total de bactérias mesófilas, utilizando-se meio de cultura específico para coliformes, recomendado para o sistema Simplate.

Após o período de incubação, realizourse a leitura a olho nú das cavidades positivas, de coloração púrpura, as quais indicam a presença de coliformes totais. $\mathrm{O}$ composto vermelho clorofenol $\beta$-D-galactopiranosídeo $(\mathrm{CPRG})$, presente no meio de cultura, quando hidrolisado pela enzima $\beta$-galactosidase produzida pelos coliformes, forma o composto vermelho clorofenol (CPR), que possui coloração laranja a púrpura. Estas cavidades de cor púrpura, se fluorescentes sob luz UV (365 nm) indicam a presença de $E$. coli, pois o composto 4-metilumbeliferil- $\beta$-D glicuronídeo (MUG), presente no meio de cultura, quando hidrolisado pela enzima $\beta$-glicuronidase, produzida por E. coli, forma o composto 4-metilumbeliferona (4MU) que apresenta-se azul fluorescente quando exposto a luz UV de $365 \mathrm{~nm}$ de comprimento de onda. 


\section{$\underline{\text { Análises Sensoriais }}$}

Foram realizadas no Laboratório de Análise Sensorial do Departamento de Agroindústria, Alimentos e Nutrição. Os provadores avaliaram as amostra em cabines individualizadas. Cada provador recebeu $30 \mathrm{~g}$ de produto por amostra devidamente codificada, juntamente com a ficha de avaliação (vide ANEXO) e água para lavagem da boca entre as avaliações.

Os provadores avaliaram primeiro o aroma e o sabor do produto em cabines com lâmpadas vermelhas para mascarar a cor. Posteriormente, avaliaram a aparência em cabine dotada de lâmpada fluorescente. As amostras de aparência continham aproximadamente $200 \mathrm{~g}$ de melão.

As avaliações foram realizadas por uma equipe de 17 provadores não treinados, utilizando-se escala hedônica de 9 pontos, variando de 9 (gostei extremamente) a 1 (desgostei extremamente) (Peryam \& Girardot, 1952).

\section{Análises físico-químicas:}

a) Escurecimento: Determinado com colorímetro Minolta, modelo CR-300, tomando-se leitura na região placentária do cubo. As leituras foram realizadas em 6 cubos por repetição e os resultados expressos em Luminosidade ( $\left.\mathrm{L}^{*}\right)$.

b) Firme za da polpa: Determinada com penetrômetro digital, ponteira $8 \mathrm{~mm}$, tomandose uma leitura na região placentária do cubo. As leituras foram realizadas em 6 cubos por repetição e os resultados expressos em Newton $(\mathrm{N})$.

c) Teor de Sólidos Solúveis Totais (SST): Leitura direta em refratômetro digital Atago modelo Palete 101, utilizando-se polpa homogeneizada em triturador doméstico tipo “mixer". Os resultados foram expressos em ${ }^{\circ}$ Brix.

d) pH: Leitura em solução de polpa homogeneizada, com pHmetro marca Tecnal. 


\subsection{Resultados e Discussão}

\section{Composição gasosa no espaço livre das embalagens}

Na Figura 1 observa-se alta eficiência na modificação ativa da atmosfera na embalagem, ou seja, o ar ambiente do interior das embalagens foi totalmente substituído pela mistura gasosa de $5 \% \mathrm{O}_{2}+20 \% \mathrm{CO}_{2}+75 \% \mathrm{~N}_{2}$. Analisando a evolução da composição gasosa do interior das embalagens, verifica-se que o filme BB-200 promoveu acúmulo de $\mathrm{CO}_{2}$ e redução de $\mathrm{O}_{2}$ do interior da embalagem ao longo do armazenamento, atingindo níveis de $24 \% \mathrm{CO}_{2}$ e $0,4 \% \mathrm{O}_{2}$. Embora a taxa respiratória do melão seja bastante baixa este comportamento era esperado, devido a baixa taxa de permeabilidade deste filme aos gases $\mathrm{O}_{2}$ e $\mathrm{CO}_{2}$ (Tabela 1).

Os filmes PBC e PP permitiram a gradativa saída de $\mathrm{CO}_{2}$ e entrada de $\mathrm{O}_{2}$ nas embalagens ao longo do armazenamento. A composição gasosa nestas embalagens ao final de 12 dias foi de aproximadamente $4 \% \mathrm{CO}_{2}$ e $8 \% \mathrm{O}_{2}$ no filme $\mathrm{PBC}$ e $6 \% \mathrm{CO}_{2}$ e $13 \% \mathrm{O}_{2}$ no filme PP. Portanto, a atmosfera manteve-se com maior modificação no filme BB-200, seguido pelo PBC e por último o PP. Este comportamento dos filmes é compatível com a taxa de permeabilidade dos mesmos que segue a ordem inversa da modificação da atmosfera (Tabela 1), ou seja, os filmes mais permeáveis permitiram maior perda da atmosfera introduzida no interior da embalagem.

As diferenças de composição gasosa no interior das embalagens são devida às características de permeabilidade dos filmes, uma vez que a relação entre a área de permeação/massa de melão foi muito semelhante nos três tratamentos. 


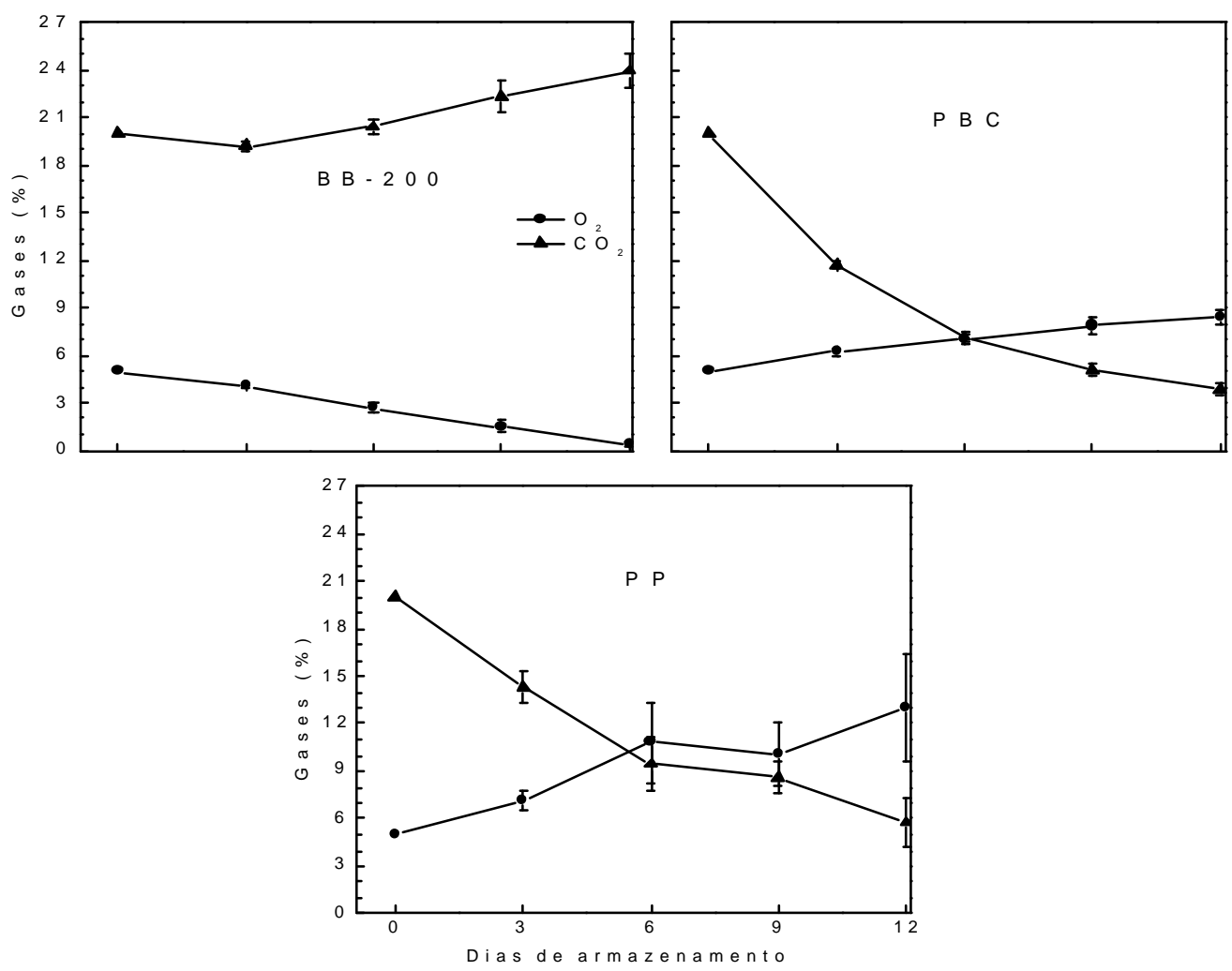

Figura 1- Evolução da composição gasosa no espaço livre das embalagens com melão minimamente processado armazenado a $3^{\circ} \mathrm{C}$, sendo: BB-200: filme multicamada da Cryovac 65 $4 \mathrm{~m}$; PBC: filme poliolefínico Probag Conservax $64 \mu \mathrm{m}$; PP: filme de polipropileno $52 \mu \mathrm{m}$.

Tabela 1. Características dos materiais de embalagem

\begin{tabular}{cccc}
\hline Embalagens & $\begin{array}{c}\text { Espessura } \\
(\mu \mathrm{m})\end{array}$ & $\begin{array}{c}\mathrm{TPO}_{2} \\
\left(\mathrm{~cm}^{3} \cdot \mathrm{m}^{-2} \cdot \mathrm{dia}^{-1}\right)\end{array}$ & $\begin{array}{c}\mathrm{TPCO}_{2} \\
\left(\mathrm{~cm}^{3} \cdot \mathrm{m}^{-2} \cdot \mathrm{dia}^{-1}\right)\end{array}$ \\
\hline BB-200 & 65 & 9 & 25 \\
$\mathrm{PBC}^{2}$ & 64 & 1.005 & 7.991 \\
$\mathrm{PP}^{3}$ & 52 & 1.961 & 6.821 \\
\hline $\begin{array}{l}1 \\
\text { polipropileno } 52 \mu \mathrm{m} .\end{array}$ & &
\end{tabular}


Tabela 2. Características das embalagens

\begin{tabular}{|c|c|c|c|}
\hline Embalagens & $\begin{array}{c}\text { Área efetiva de } \\
\text { permeação }{ }^{\mathrm{A}}\left(\mathrm{cm}^{2}\right)\end{array}$ & $\begin{array}{c}\text { Massa de melão } \\
\text { (g) }\end{array}$ & Relação A/B $\left(\mathrm{cm}^{2} / \mathrm{g}\right)$ \\
\hline $\mathrm{BB}^{2}-200^{1}$ & 892 & 240 & 3,72 \\
\hline $\mathrm{PBC}^{2}$ & 858 & 240 & 3,58 \\
\hline $\mathrm{PP}^{3}$ & 880 & 240 & 3,67 \\
\hline
\end{tabular}

\section{Análise microbiana}

Pelas Tabelas 3 e 4 observa-se que os melões controle apresentaram durante o período de armazenamento as maiores contagens totais de bactérias aeróbias mesófilas e também de bactérias do grupo coliformes totais.

Verifica-se que a partir do $9^{\circ}$ dia, a contagem total de bactérias mesófilas ultrapassou $738 \times 10^{3} \mathrm{NMP} / \mathrm{g}$, não sendo possível determinar o número mais provável, nas amostras controle, pois na maior diluição utilizada, todas as cavidades se mostraram positivas. Nos demais tratamentos os NMP puderam ser determinados e não excederam $8,3 \times 10^{3} \mathrm{NMP} / \mathrm{g}$ de produto. Dessa forma, conclui-se que o uso de atmosfera modificada contribui para a redução da microbiota bacteriana total.

A análise realizada para a contagem total de bactérias mesófilas, visa a deteç̧ão das bactérias aeróbias que crescem bem entre 15 e $45^{\circ} \mathrm{C}$, e como as amostras de melão permaneceram armazenadas a $3^{\circ} \mathrm{C}$, provavelmente as contagens efetuadas nesta análise contemplaram também as bactérias psicotróficas, cujo ótimo de temperatura situa-se acima de $20^{\circ} \mathrm{C}$, porém toleram e crescem sob refrigeração. Este fato talvez seja a explicação para o pequeno aumento verificado nas amostras embaladas nos filmes PBC e PP ao longo do armazenamento, onde a modificação da atmosfera reduziu o crescimento de bactérias aeróbias e para o grande aumento nas contagens das amostras controle onde só a temperatura de armazenamento não foi suficiente para inibir o crescimento bacteriano. 
Bai et al. (2001) avaliaram materiais de embalagem para melões Cantaloupe minimamente processados e verificaram que a população microbiana foi maior nos melões acondicionados em embalagem microperfuradas, onde praticamente não houve modificação da atmosfera.

No presente trabalho os valores iniciais da microbiota bacteriana total encontrados no dia do processamento apresentaram-se superiores aos valores obtidos no

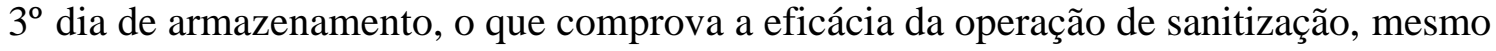
durante poucos segundos. Beuchat \& Brackett (1990) citam que a imersão de frutas e hortaliças em água clorada, por, no mínimo, 30 segundos, é suficiente para inativação de microrganismos.

No presente trabalho a imersão dos pedaços de melões em água clorada foi feita por apenas 3 segundos, em virtude da alta capacidade de absorção de água pelo melão, o que poderia causar mudanças no sabor, caso a imersão fosse por mais tempo. Entretanto, o tempo utilizado mostrourse eficiente.

Os melões acondicionados na embalagem BB-200 sob atmosfera com alta concentração de $\mathrm{CO}_{2}$ e baixa concentração de $\mathrm{O}_{2}$ apresentaram menores valores de contaminação bacteriana, comprovando o descrito por Farber (1991), que cita o $\mathrm{CO}_{2}$ como principal responsável pelo efeito bacteriostático observado em microrganismos crescendo em produtos minimamente processados.

Pela Tabela 4 é possível notar que também para as bactérias coliformes, a embalagem BB-200 foi a que apresentou melhor resultado na inibição dessas bactérias. No caso das bactérias coliformes totais a diferença da ação inibidora da embalagem BB200 não foi tão pronunciada como aquela verificada na análise de bactérias mesófilas totais. Mais uma vez foi possível observar que nas amostras controle houve aumento da população de bactérias coliformes totais ao longo do armazenamento.

No caso das bactérias coliformes, que são anaeróbias facultativas, a modificação da atmosfera nas embalagens não surtiu tanto efeito como aquele verificado para as bactérias mesófilas totais. Neste caso o efeito da temperatura de armazenamento $\left(3^{\circ} \mathrm{C}\right)$ provavelmente tenha sido o fator principal da inibição bacteriana, uma vez que as bactérias coliformes são mesófilas. 
Em nenhuma das amostras de melão analisadas houve detecção de E.coli, o que as colocam em conformidade com os padrões estabelecidos pela Resolução RDC $\mathrm{n}^{\mathbf{0}} 12$ de 02 de janeiro de 2002 da Agência Nacional de Vigilância Sanitária do Ministério da Saúde. A referida resolução estabelece como padrão, o máximo de $5 \times 10^{2} \mathrm{NMP}$ de coliformes fecais por grama de fruta. Embora não existam na legislação padrões para bactérias mesófilas totais e coliformes totais, de forma geral, é preconizado que alimentos contendo contagens microbianas da ordem de $10^{5}-10^{6} \mathrm{UFC} / \mathrm{g}$ são impróprios para o consumo humano devido a perda do valor nutricional, alterações organolépticas, riscos de deterioração e/ou presença de patógenos. No presente trabalho, apenas as amostras de melões acondicionadas em embalagem sem atmosfera modificada apresentaram, a partir do $9^{\circ}$ dia de amazenamento, contagens totais de bactérias mesófilas acima de $10^{5} \mathrm{NMP} / \mathrm{g}$, o que poderia torná-las impróprias para o consumo humano, pelos motivos já expostos.

Tabela 3. NMP de bactérias mesófilas totais, em melão minimamente processado armazenado a $3^{\circ} \mathrm{C}$ sob atmosfera modificada ativa, segundo a metodologia Simplate.

\begin{tabular}{ccccc}
\hline Materiais de & \multicolumn{4}{c}{ Dias de armazenamento } \\
Embalagem & 3 & 6 & 9 & 12 \\
\hline BB-200 & $<0,2 \times 10^{3}$ & $<0,2 \times 10^{3}$ & $0,4 \times 10^{3}$ & $0,4 \times 10^{3}$ \\
PBC & $<0,2 \times 10^{3}$ & $<0,2 \times 10^{3}$ & $1,5 \times 10^{3}$ & $7,4 \times 10^{3}$ \\
PP-10 & $1,2 \times 10^{3}$ & $0,6 \times 10^{3}$ & $5,6 \times 10^{3}$ & $8,3 \times 10^{3}$ \\
Controle & $1,7 \times 10^{3}$ & $12,4 \times 10^{3}$ & $>738 \times 10^{3}$ & $>738 \times 10^{3}$ \\
\hline
\end{tabular}

Início: NMP de $3 \times 10^{3} / \mathrm{g}$.

Os resultados obtidos representam a média aritmética do NMP ( $\mathrm{n}^{\circ}$ mais provável) / $\mathrm{g}$ de produto. 
Tabela 4. NMP de coliformes totais, em melão minimamente processado armazenado a $3^{\circ} \mathrm{C}$ sob atmosfera modificada ativa, segundo a metodologia Simplate.

\begin{tabular}{ccccc}
\hline $\begin{array}{c}\text { Materiais de } \\
\text { embalagem }\end{array}$ & 3 & \multicolumn{4}{c}{ Dias de armazenamento } \\
\hline BB-200 & $<0,2 \times 10^{3}$ & $<0,2 \times 10^{3}$ & $<0,2 \times 10^{3}$ & $0,2 \times 10^{3}$ \\
PBC & $<0,2 \times 10^{3}$ & $0,2 \times 10^{3}$ & $0,8 \times 10^{3}$ & $<0,2 \times 10^{3}$ \\
PP-10 & $<0,2 \times 10^{3} 0$ & $<0,2 \times 10^{3}$ & $1,2 \times 10^{3}$ & $<0,2 \times 10^{3}$ \\
Controle & $<0,2 \times 10^{3}$ & $<0,2 \times 10^{3}$ & $2,8 \times 10^{3}$ & $4 \times 10^{3}$ \\
\hline
\end{tabular}

Início: NMP de1,9 x $10^{3} / \mathrm{g}$ de produto

Os resultados obtidos representam a média aritmética do NMP ( $\mathrm{n}^{\circ}$ mais provável) / g de produto.

Tabela 5. NMP de E. coli, em melão minimamente processado armazenado a $3^{\circ} \mathrm{C}$ sob atmosfera modificada ativa, segundo a metodologia Simplate.

\begin{tabular}{ccccc}
\hline $\begin{array}{c}\text { Materiais de } \\
\text { embalagem }\end{array}$ & 3 & \multicolumn{4}{c}{ Dias de armazenamento } \\
\hline BB-200 & Ausência & Ausência & Ausência & 12 \\
PBC & Ausência & Ausência & Ausência & Ausência \\
PP-10 & Ausência & Ausência & Ausência & Ausência \\
Controle & Ausência & Ausência & Ausência & Ausência \\
\hline
\end{tabular}

Início: Ausência / g de produto

\section{Análise sensorial}

Os melões acondicionados em embalagem de polipropileno apresentaram notas de aparência significativamente superiores aos demais tratamentos até o $6^{\circ}$ dia de armazenamento (Tabela 6). Nos demais períodos de armazenamento, não houve diferenças estatísticas entre os tratamentos.

Durante o período de armazenamento, as notas de aparência dos melões acondicionados nesta embalagem permaneceram semelhantes, ou seja, variando de gostei muito a gostei regularmente.

Os melões acondicionados em embalagem BB-200 e PBC mantiveram durante todo período de armazenamento notas de aparência semelhantes, variando de gostei ligeiramente a não gostei nem desgostei, enquanto os melões do grupo controle apresentaram notas de aparência entre gostei regularmente a gostei ligeiramente. 
Tabela 6. Aparência de melão rendilhado minimamente processado armazenado a $3^{\circ} \mathrm{C}$ sob atmosfera modificada ${ }^{1,2)}$

\begin{tabular}{|c|c|c|c|c|}
\hline \multirow{2}{*}{$\begin{array}{l}\text { Materiais de } \\
\text { Embalagem }\end{array}$} & \multicolumn{4}{|c|}{ Dias de armazenamento } \\
\hline & 3 & 6 & 9 & 12 \\
\hline & \multicolumn{4}{|c|}{-------------- Aparência (Notas) ----------------- } \\
\hline BB-200 & $5,76 \mathrm{c}$ & $6,19 \mathrm{~b}$ & $5,65 \mathrm{a}$ & $5,65 \mathrm{a}$ \\
\hline $\mathrm{PBC}$ & $6,00 \mathrm{bc}$ & $5,25 \mathrm{~b}$ & $5,92 \mathrm{a}$ & $5,79 \mathrm{a}$ \\
\hline PP & $8,00 \mathrm{a}$ & $7,82 \mathrm{a}$ & $7,00 \mathrm{a}$ & $7,00 \mathrm{a}$ \\
\hline Controle & $7,20 \mathrm{ab}$ & $6,33 \mathrm{~b}$ & $7,24 \mathrm{a}$ & $6,53 \mathrm{a}$ \\
\hline $\mathrm{CV}(\%)$ & 23,90 & 22,61 & 30,71 & 28,81 \\
\hline
\end{tabular}

As notas referentes ao aroma variaram de gostei regularmente a gostei ligeiramente nos melões acondicionados em embalagem de polipropileno, BB-200 e $\mathrm{PBC}$, enquanto as notas dos melões do grupo controle variaram de gostei regularmente a não gostei nem desgostei. Aos 9 dias de armazenamento, os melões do controle apresentaram notas inferiores aos demais tratamentos, diferindo estatisticamente dos melões acondicionados em embalagem BB-200. 
Tabela 7. Aroma de melão rendilhado minimamente processado armazenado a $3^{\circ} \mathrm{C} \mathrm{sob}$ atmosfera modificada ${ }^{1,2)}$

\begin{tabular}{|c|c|c|c|c|}
\hline \multirow{2}{*}{$\begin{array}{l}\text { Materiais de } \\
\text { Embalagem }\end{array}$} & \multicolumn{4}{|c|}{ Dias de armazenamento } \\
\hline & 3 & 6 & 9 & 12 \\
\hline & \multicolumn{4}{|c|}{ |--------------------- Aroma (Notas) ------------------------ } \\
\hline BB-200 & $7,00 \mathrm{a}$ & $7,29 \mathrm{a}$ & $7,03 \mathrm{a}$ & $6,65 a$ \\
\hline PBC & $6,60 \mathrm{a}$ & $6,53 \mathrm{a}$ & $6,65 \mathrm{ab}$ & $6,00 a$ \\
\hline PP & $7,13 \mathrm{a}$ & $7,00 \mathrm{a}$ & $6,71 \mathrm{ab}$ & $7,00 \mathrm{a}$ \\
\hline Controle & $7,35 \mathrm{a}$ & $6,53 \mathrm{a}$ & $5,31 \mathrm{~b}$ & - \\
\hline $\mathrm{CV}(\%)$ & 19,61 & 22,98 & 26,90 & 43,98 \\
\hline
\end{tabular}

Não foram observadas diferenças estatísticas entre os tratamentos para as notas de sabor em nenhum dos períodos de armazenamento, embora o sabor dos melões acondicionados nas embalagens BB e PP mantiveram acima do limite de aceitabilidade durante todo período de armazenamento, enquanto os melões do controle apresentaram no $9^{\circ}$ dia de armazenamento nota inferior a 5 (limite de aceitabilidade), sendo considerado com sabor de fermentado por alguns provadores. Os melões acondicionados em embalagem PBC também apresentaram alteração do sabor no $12^{\circ}$ dia. 
Tabela 8. Sabor de melão rendilhado minimamente processado armazenado a $3^{\circ} \mathrm{C}$ sob atmosfera modificada ${ }^{1,2)}$

\begin{tabular}{lcccc}
\hline \multicolumn{1}{c}{$\begin{array}{c}\text { Materiais de } \\
\text { Embalagem }\end{array}$} & 3 & \multicolumn{4}{c}{ Dias de armazenamento } \\
& \multicolumn{1}{c}{6} & 9 & 12 \\
BB-200 & $5,43 \mathrm{a}$ & $5,31 \mathrm{a}$ & $5,88 \mathrm{a}$ & $5,53 \mathrm{a}$ \\
PBC & $5,87 \mathrm{a}$ & $5,20 \mathrm{a}$ & $5,06 \mathrm{a}$ & $4,24 \mathrm{a}$ \\
PP & $6,75 \mathrm{a}$ & $6,18 \mathrm{a}$ & $5,63 \mathrm{a}$ & $5,87 \mathrm{a}$ \\
Controle & $6,65 \mathrm{a}$ & $6,41 \mathrm{a}$ & $4,88 \mathrm{a}$ & \\
CV $(\%)$ & 30,94 & 35,35 & 43,37 & 45,05 \\
\hline
\end{tabular}

${ }^{\mathrm{T}}$ Médias seguidas de mesma letra na coluna não diferem entre si, pelo teste de Tukey ao nível de 5\% de probabilidade.

2Notas: $9=$ gostei extremamente; $8=$ gostei muito; $7=$ gostei moderadamente; $6=$ gostei ligeiramente; $5=$ não gostei nem desgostei; 4=desgostei ligeiramente; $3=$ desgostei moderadamente; $2=$ desgostei muito; $1=$ desgostei extremamente)

\section{Análise físico-química}

A Tabela 9 indica os valores de coloração expressos em Luminosidade(L), sendo que os menores valores de L representam maior escurecimento da polpa de melão, na região placentária.

Observa-se que a embalagem PP propiciou valores significativamente maiores de L em relação às embalagens BB-200 e PBC em todo período de armazenamento e em relação ao controle no $6^{\circ}$ e $9^{\circ}$ dia de armazenamento. Estes resultados refletiram na boa aparência do produto, onde os melões acondicionados na embalagem PP apresentaram notas de aparência superior a 7, correspondente ao termo 'gostei moderadamente' (Tabela 6) durante todo período de armazenamento. 
Tabela 9. Escurecimento da polpa de melão rendilhado minimamente processado armazenado a $3^{\circ} \mathrm{C}$ sob atmosera modificada.

\begin{tabular}{|c|c|c|c|c|}
\hline \multirow{2}{*}{$\begin{array}{l}\text { Materiais de } \\
\text { Embalagem }\end{array}$} & \multicolumn{4}{|c|}{ Dias de armazenamento } \\
\hline & 3 & 6 & 9 & 12 \\
\hline & ------------ & --- Lum & $(\mathrm{L})$----. & $--\cdot$ \\
\hline BB-200 & $52,51 \mathrm{~b}$ & $54,08 \mathrm{~b}$ & $56,03 \mathrm{~b}$ & $50,42 \mathrm{~b}$ \\
\hline PBC & $52,71 \mathrm{~b}$ & $55,53 \mathrm{~b}$ & $55,86 \mathrm{~b}$ & $49,08 \mathrm{~b}$ \\
\hline PP & $61,71 \mathrm{a}$ & 63,95 a & $63,51 \mathrm{a}$ & $61,50 \mathrm{a}$ \\
\hline Controle & $56,06 \mathrm{ab}$ & $56,26 \mathrm{~b}$ & $57,11 \mathrm{~b}$ & $58,50 \mathrm{ab}$ \\
\hline $\mathrm{CV}(\%)$ & 5,74 & 4,57 & 4,04 & 8,60 \\
\hline
\end{tabular}

Valor inicial: 64,81

Não houve efeito da alteração da composição gasosa sobre a firmeza, sólidos solúveis totais e pH dos melões. A Tabela 10 apresenta os valores médios destas variáveis.

Tabela 10. Valores médios de firmeza e $\mathrm{pH}$ da polpa de melão rendilhado minimamente processado armazenado a $3^{\circ} \mathrm{C}$ sob atmosfera modificada.

\begin{tabular}{lcccc}
\hline \multicolumn{1}{c}{ Variáveis } & \multicolumn{4}{c}{ Materiais de embalagem } \\
& BB-200 & PBC & PP & Controle \\
\hline Firmeza (N) & 2,15 & 2,07 & 2,50 & 2,48 \\
Sólidos Solúveis & 7,37 & 7,38 & 7,36 & 8,58 \\
Totais ( ${ }^{\circ}$ Brix) & & & & 5,82 \\
PH & 5,78 & 5,80 & 5,76 & \\
\hline
\end{tabular}

A alteração da composição gasosa teve pouca influência nas características físicoquímica e sensoriais dos melões. No entanto, os melões do controle apresentaram sabor abaixo do limite de aceitabilidade no $9^{\circ}$ dia e aqueles acondicionados em filme PBC, no $12^{\circ}$ dia. Em relação às características microbiológicas, apenas os melões controle apresentaram contagem total de bactérias mesófilas acima de $10^{5} \mathrm{NMP} / \mathrm{g}$, com riscos de 
deterioração e/ou presença de patógenos. Não foram detectados Escherichia coli em nenhum dos tratamentos, demonstrando a eficácia dos cuidados higiênico-sanitários realizados durante as etapas do processamento

\subsection{Conclusões}

- Melões minimamente processados armazenados a $3^{\circ} \mathrm{C}$ sem atmosfera modificada podem ser conservados por 6 dias.

- Melões minimamente processados acondicionados em embalagem $\mathrm{PBC}$ com $5 \% \mathrm{O}_{2}$ $+20 \% \mathrm{CO}_{2}+75 \% \mathrm{~N}_{2} \mathrm{e}$ armazenados a $3^{\circ} \mathrm{C}$ podem ser conservados por 9 dias.

- Melões minimamente processados acondicionados em embalagem BB-200 ou PP com $5 \% \mathrm{O}_{2}+20 \% \mathrm{CO}_{2}+75 \% \mathrm{~N}_{2}$ e armazenados a $3^{\circ} \mathrm{C}$ podem ser conservados por 12 dias. 


\section{CONCLUSÕES GERAIS}

- Melões rendilhados podem ser minimamente processados na forma de cubos ou fatias.

- A temperatura ideal para armazenamento de melões rendilhados minimamente processados é $3^{\circ} \mathrm{C}$.

- $\mathrm{O}$ armazenamento de melão minimamente processado armazenado a $3^{\circ} \mathrm{C}$ sem atmosfera modificada pode ser realizado por até 6 dias.

- Melões minimamente processados acondicionados em embalagem PBC com 5\% de $\mathrm{CO}_{2}+20 \% \mathrm{O}_{2}+75 \% \mathrm{~N}_{2}$ e mantidos a $3^{\circ} \mathrm{C}$ podem ser armazenados por até 9 dias.

- Melões minimamente processados acondicionados em embalagem BB-200 ou PP com $5 \% \mathrm{O}_{2}+20 \% \mathrm{CO}_{2}+75 \% \mathrm{~N}_{2}$ e mantidos a $3^{\circ} \mathrm{C}$ podem ser armazenados por até 12 dias.

- A atmosfera modificada mostrou-se eficiente no controle de microrganismos. 
ANEXO 


\section{Modelo da ficha de avaliação sensorial}

Nome:

Telefone:

Data:

Amostra $n^{\circ}$ :

Muito obrigado por participar de nossa pesquisa com melão minimamente processado. Você receberá 4 amostras de melão para avaliar aroma e sabor.

1.Indique o quanto você gostou do aroma do produto:

( ) 9.gostei extremamente

( ) 8.gostei muito

( ) 7.gostei regularmente

( ) 6.gostei ligeiramente

( ) 5.não gostei nem desgostei

( ) 4.desgostei ligeiramente

( ) 3.desgostei regularmente

( ) 2.desgostei moderadamente

( ) 1.desgostei extremamente

2.Indique o quanto você gostou do sabor do produto:

( ) 9.gostei extremamente

( ) 8.gostei muito

( ) 7.gostei regularmente

( ) 6.gostei ligeiramente

( ) 5.não gostei nem desgostei

( ) 4.desgostei ligeiramente

( ) 3.desgostei regularmente

( ) 2.desgostei moderadamente

( ) 1.desgostei extremamente

Por favor, indique o que em particular você mais gostou ou menos gostou neste produto (use palavras ou frases):

Mais gostei:

Menos gostei: 
Nome:

Telefone:

Data:

Amostra $n^{\circ}:$

Muito obrigado por participar de nossa pesquisa com melão minimamente processado. Você receberá 4 amostras de melão para avaliar a aparência do produto.

1.Indique o quanto você gostou do aparência do produto:

( ) 9.gostei extremamente

( ) 8.gostei muito

( ) 7.gostei regularmente

( ) 6.gostei ligeiramente

( ) 5.não gostei nem desgostei

( ) 4.desgostei ligeiramente

( ) 3.desgostei regularmente

( ) 2.desgostei moderadamente

( ) 1.desgostei extremamente

Por favor, indique o que em particular você mais gostou ou menos gostou neste produto (use palavras ou frases):

Mais gostei:

Menos gostei: 


\section{REFERÊNCIAS BIBLIOGRÁFICAS}

AGÊNCIA NACIONAL DE VIGILÂNCIA SANITÁRIA. Resolução - RDC no 12, de 2 de janeiro de 2001. www.anvisa.gov.br/legis/resol/12_01rdc.htm (21 fev. 2002).

ALLONG, R.; WICKHAM, L.D.; MOHAMMED, M. The effect of cultivar, fruit ripeness, storage temperature and duration on quality of fresh-cut mango. Acta Horticulturae, n.509, p.487-494, 2000.

ALVES, R. E. (Org.) Melão: pós-colheita. Brasília: Embrapa Comunicação para Transferência de Tecnologia, 2000. 43p. (Frutas do Brasil, 10).

ARAUJO, J.P. Cultura do melão. Petrolina: EMBRAPA, Centro de Pesquisa Agropecuária do Trópico Semi-Árido, 1980. 40p.

AVAKIAN. Melons. www.producepair.com/melons.htlm. (20 out. 2001).

BAI, J.H.; SAFTNER, R.A.; WATADA, A.E. et al. Modified atmosphere maintains quality of fresh cut Cantaloupe (Cucumis melo L.). Journal of Food Science, v.66, n.8, p.1207-1211, 2001.

BARRIGA, M.I.; TRACHY, G.; WILLEMOT, C. et al. Microbial changes in shredded iceberg lettuce stored under controlled atmosphere, Journal of Food Science, v.56, p.1586, 1991. 
BLEINROTH, E.W. Determinação do ponto de colheita. In: GORGATTI NETO, A.; GAYET, J.P.; BLEINROTH, E.W. et al. Melão para exportação: procedimentos de colheita e pós-colheita. Brasília: Embrapa, Spi, 1994. p.11-21 (FRUPEX. Série Publicações Técnicas, 6).

BRADY, C.J.; YOUNG, R.E. Fruit ripening. Annual Review of Plant Physiology, v.38, p.155-178, 1987.

BRANDÃO FILHO, J.V.T.; VASCONCELLOS, M.A.S. A cultura do meloeiro. In: GOTO, R.; TIVELLI, S.W. (Ed.). Produção de hortaliças em ambiente protegido: condições subtropicais. São Paulo: Fundação Editora da UNESP, 1998. p.161-193.

BRECHT, J.K. Physiology of lightly processed fruits and vegetables. HortScience, v.30, n.1, p.18-22, 1995.

BURNS, J.K. Lightly processed fruits and vegetables: Introduction to the Colloquium. HortScience, v.30, n.1, p.14-17, 1995.

CANTWELL, M. Postharvest handling systems: minimally processed fruits and vegetables. In: KADER, A.A. (Ed.) Postharvest technology of horticultural crops. 2.ed. Davis: University of California, Dir. Agric. Nat. Res., 1992. p.277-281. (Publication, 3311).

CANTWELL, M. Preparation and quality of fresh produce: In: ENCONTRO NACIONAL SOBRE PROCESSAMENTO MÍNIMO DE FRUTAS E HORTALIÇAS, 2., Viçosa 2000. Palestras. Viçosa, UFV, 2000. p.150-172.

CHITARRA, M.I.F. Processamento mínimo de frutos e hortaliças. Viçosa: Centro de Produções Técnicas, 1998. 88p. 
CHITARRA, M.I.F.; CHITARRA, A.B. Pós-colheita de frutos e hortaliças: fisiologia e manuseio. Lavras: ESAL, Fundação de Apoio ao Ensino, Pesquisa e Extensão, 1990. 293p.

CRYOVAC DIVISION. New controlled permeability produce packaging preserves flavors and extends shelf life. Ontario, 1994. 15p.

DAREZZO, H.M. Processamento mínimo de alface (Lactuca sativa L.). In: ENCONTRO NACIONAL SOBRE PROCESSAMENTO MÍNIMO DE FRUTAS E HORTALIÇAS, 2., Viçosa, 2000. Palestras. Viçosa: Universidade Federal de Viçosa, 2000. p.117-124.

DURIGAN, J.F.; SARGENT, S.A. Uso do melão Cantaloupe na produção de produtos minimamente processados. Alimentos e Nutrição, v.10, p.69-77, 1999

FARBER, J.M. Microbiological aspects of modified atmosphere packaging technology a review. Journal of Food Protection. V.54, n.1, p.58-70, 1991.

FNP CONSULTORIA \& COMÉRCIO. Agrianual 2000: anuário da agricultura brasileira. São Paulo, 2000. p.34-45: Horticultura.

FNP CONSULTORIA \& COMÉRCIO. Agrianual 2002: anuário da agricultura brasileira. São Paulo, 2002. p.412-416: Melão.

HAJDENWURCEL, J.R. Atlas de microbiologia de alimentos. São Paulo: Fonte, 1998. 66p.

HILDEBRAND, D.F. Lipoxygenases. Plant Physiology, v.76, p.249-253, 1989. 
HIRAISHI, A.; HORIE, S. Species composition and growth temperature characteristics of coliforms in relation to their sources. Journal of General Applied Microbiology, v.28, p.139-154, 1982.

HOTCHKISS, J.H. Safety considerations in active packaging. In: ROONEY, M.L. Active food packaging. Glasgow: Chapman \& Hall, 1995. p.238-255.

INTERNATIONAL COMMISSION ON MICROBIOLOGICAL SPECIFCATIONS FOR FOODS. Microorganisms in foods. 2.ed. Toronto: University of Toronto Press, 1978. v.1, 434p.

INTERNATIONAL FRESH PRODUCT ASSOCIATION. Fresh-cut produce handling guidelines. 3 ed. Newark: Produce Marketing Association, 1999. 39p.

KADER, A.A. Biochemical and physiological basics for effects of controlled and modified atmospheres on fruits and vegetable. Food Technology, v.40, n.5, p.99104, 1986.

KADER, A.A. Postharvest biology and technology: an overview. In:KADER.A.A. (Ed.) Postharvest technology of horticultural crops. Oakland: University of California, 1992. cap.3, p.15-20.

KADER, A. A.; KE, D. Controlled atmospheres. In: PAULL, R. E.; ARMSTRONG, J. W. (Ed.) Insect pest and fresh horticultural products: treatments and responses. Wallingford: CAB Internation, 1994. p.223-236.

LAMIKANRA, O.; CHEN, J.C.; BANKS, D. et al. Biochemical and microbial changes during the storage of minimally processes cantaloupe. Journal of agricultural and food chemistry, v.48, p.5955-5961, 2000. 
LAMIKANRA, O.; WATSON, M.A. Cantaloupe melon peroxidase: Characterization and effects of additivies on activity. Nahrung, v.44, n.3, p.168-172, 2000.

LUENGO, R. F. A.; LANA, M. M. Processamento mínimo de hortaliças. Brasília: EMBRAPA Hortaliças, 1997. 3p. (Comunicado Técnico, 2 ).

MATHOOKO, F.M. Regulation of ethylene biosynthesis in higher plants by carbon dioxide. Postharvest Biology and Technology, v.7, p.1-26, 1996.

MENEZES, J.B.; CHITARRA, A.B.; CHITARRA, M.I.F. et al. Caracterização póscolheita do melão amarelo 'AGROFLORA 646'. Horticultura Brasileira, v.13, n.2, p. $150-153,1995$.

MORETTI, C.L. Processamento mínimo de hortaliças: alternativa viável para a redução de perdas pós-colheita e agregação de valor ao agronegócio brasileiro. Horticultura Brasileira, v.17, n.2, p.1, 1999.

NGUYEN-the, C. , CARLIN, F. The microbiology of minimally proceesed fresh fruits and vegetables. Critical Reviews in Food Science and Nutrition, v.34, n.4, p. 371401, 1994.

O'CONNOR-SHAW, R.E.; ROBERTS, R.; FORD, A.L. et al. Shelf life of minimally processed honeydew, kiwifruit, papaya, pineapple and cantaloupe. Journal of Food Science, v.59, n.6, p.1202-1206, 1215, 1994.

OLIVEIRA, L.M.; ALVES, R.M.V.; SARANTÓPOULOS, C.I.G.L. et al. Ensaios para avaliação de embalagens plásticas flexíveis. Campinas:ITAL, CETEA, 1996.219p.

PERYAM, D.R.; GIRARDOT, N.F. Advanced taste method. Food Engeneiring, v.24, p.58-61, 1952. 
PORTELA, S.; NIE, X.; SUSLOW, T. et al. Changes in sensory quality and fermentative volatile concentrations of minimally processed cantaloupe stored in controlled atmospheres. In: INTERNATIONAL CONTROLLED RESEARCH CONFERENCE, 7., Davis, 1997 Proceedings. Davis: University of California, 1997. p.123-129.

PORTELA, S.I.; CANTWELL, M.I. Quality changes of minimally processed honeydew melons stored in air or controlled atmosphere. Postharvest Biology and Technology, v.14, p.351-357, 1998.

ROSEN, J.; KADER, A.A. Postharvest physiology and quality maintenance os sliced pear and strawberry fruits. Journal of Food Science, v.54, p.656-659, 1989.

ROSTELATO, C. Melão-de-renda é nova opção para estufas. Suplemento Agrícola, n.2187, p.G3, out.1997.

SARANTÓPOULOS, C.I.G.L.; ALVES, R.M.V.; OLIVEIRA, L.M.de. et al. Embalagens com atmosfera modificada. 2.ed. Campinas: CETEA, ITAL, 1996. $114 \mathrm{p}$.

SARGENT, S. A. Fresh-cut watermelon: maintaining quality from processor to supermarket. Citrus \& Vegetable Magazine, p.24-25, v.2, Feb.1999.

SHELLIE, K.C.; SALTVEIT Jr., M.E. The lack of a respiratory rise in muskmelon fruit ripening on the pkant challenges the definition of climacteric behaviour. Journal of Experimental Botany, v.44, n.265, p.1403-1406, Aug.1993.

SHEWFELT, R.L. Postharvest treatment for extending the shelf life of fruits and vegetables. Food Technology, n.5, p.70-80, 1987. 
TATSUMKI, Y.; WATADA, A. E.; WERGIN, W. P. Scanning electron microscopy of carrot stick surface to determine cause of white translucent appeareance. Journal of Food Science, v.56, p.1357-1362, 1991.

VAROQUAUX, P.; LECENDRE, I.; VAROQUAUX, F. et al. Change in Firmness of kiwi after slicing. Sciences des aliments, v.10, n.1, p.127-139, 1990.

WILEY, R.C. Minimally processed refrigerated fruits and vegetables. New York: Chapman \& Hall, 1994. 368p.

YAM, K.L.; LEE, D.S. Design of modified atmosphere packaging for fresh produce. In: ROONEY, M.L. Active food packaging. Glasgow: Chapman \& Hall, 1995. p.5573.

ZAGORY, D.; KADER, A.A. Modified atmosphere packaging of fresh produce. Food Technology, v.42, n.9, p.70-77, 1988.

ZAPATA NICOLAS, M.; CABRERA FERNANDEZ, P.; BAÑON ARIAS, S. et al. EI melon. Madrid: Mundi-Prensa, 1989.174p. 